\title{
Mortgage Selection: Interactive Effects of House Price Appreciation and Mortgage Pricing Components
}

\author{
Frederick Furlong \\ Federal Reserve Bank of San Francisco \\ Yelena Takhtamanova \\ Federal Reserve Bank of San Francisco \\ David Lang \\ Stanford University
}

March 2019

Working Paper 2016-28

https://www.frbsf.org/economic-research/publications/working-papers/2016/28/

\section{Suggested citation:}

Furlong, Frederick, Yelena Takhtamanova, David Lang. 2019. “Mortgage Selection: Interactive Effects of House Price Appreciation and Mortgage Pricing Components” Federal Reserve Bank of San Francisco Working Paper 2016-28. https://doi.org/10.24148/wp2016-28

The views in this paper are solely the responsibility of the authors and should not be interpreted as reflecting the views of the Federal Reserve Bank of San Francisco or the Board of Governors of the Federal Reserve System. 


\title{
Mortgage Selection: Interactive Effects of House Price Appreciation AND MorTGage PRICING COMPONENTS ${ }^{1}$
}

\author{
Frederick T. Furlong \\ Federal Reserve Bank of San Francisco \\ Yelena Takhtamanova \\ Federal Reserve Bank of San Francisco \\ David Lang \\ Stanford University
}

March 2019

\begin{abstract}
Research has shown evidence of a link between house price appreciation and the selection of mortgage financing options: Higher appreciation is associated with higher take-up rates for adjustable-rate mortgages relative to fixed-rate mortgages. Research also finds that mortgage interest rates and their underlying components are important determinants of take-up rates among mortgage financing options. In this paper we show that house price appreciation can have important interactive effects with those other determinants of mortgage financing outcomes. We focus on the period from 2000 to 2007, an episode marked by rapid house price appreciation along with a persistent and notable increase in the use of adjustable-rate mortgage financing, including alternative mortgage products. Empirical analysis indicates that higher house price appreciation dampened the estimated effect of the mortgage pricing components on the probabilities of mortgage financing outcomes. The results, which are especially robust for fixedrate and adjustable-rate mortgages that are fully amortized, are not driven solely by markets with especially high rates of house price appreciation. Moreover, after taking into account the interactive effects with mortgage pricing components, house price appreciation has relatively little additional effect on take-up rates among mortgage financing options.

JEL Codes: D1, G11, G21, R2

Keywords: mortgage selection, mortgage choice, mortgage contracts, household finance, fixedrate, adjustable-rate

The views in this paper are solely the responsibility of the authors and should not be interpreted as reflecting the views of the Federal Reserve Bank of San Francisco or the Board of Governors of the Federal Reserve System.
\end{abstract}

\footnotetext{
${ }^{1}$ An earlier version of this study was titled "Mortgage Choice in the Housing Boom: Impact of House Price Appreciation and Borrower Type,” Federal Reserve Bank of San Francisco, Working Paper 2016-28.
} 


\section{Introduction}

An important part of the mortgage financing decision is the borrower's selection from among various fixed-rate and adjustable-rate contracts. Previous research consistently finds that mortgage interest rates and their underlying components, such as interest rate term premiums and the term structure of expected short-term interest rates, are related to the take-up rates of among mortgage financing options (see, for example, Dhillon et al. (1987), Vickery (2007), Koijen et al. (2009), Elliehausen and Hwang (2010), and Krainer (2010)). Theoretical modeling of mortgage choice and empirical evidence also indicate that house price appreciation can affect borrowers' selections among fixed-rate and adjustable-rate mortgages, with higher appreciation favoring the take-up of adjustable-rate mortgages (see, for example, Elliehausen and Hwang (2010) and Krainer (2010), Piskorski and Tchistyi (2011)).

We extend the earlier research by showing that house price appreciation can have important interactive effects with mortgage pricing components on borrowers' take-up rates among mortgage financing options. Our analysis focuses on the period from 2000 to 2007, an episode marked by rapid house price appreciation in many markets along with a persistent and notable increase in the use of adjustable-rate mortgage financing, including alternative mortgage products. We find that higher house price appreciation dampened the estimated effect of the mortgage pricing components on the probabilities of mortgage financing outcomes. The magnitudes of the dampening effects are estimated to be somewhat larger at higher levels of appreciation. Moreover, after controlling for the interactive effects, house price appreciation is estimated to have relatively little additional effect on take-up rates among mortgage financing options.

The dampening effects of house price appreciation could be consistent with rational consumer choices or with speculative bubbles associated with the housing boom. To the extent there were price bubbles in housing markets in 2000 to 2007 period, the degree of house price appreciation could have affected the relation of traditional determinants of mortgage financing outcomes in general, including mortgage pricing components. Shiller (2013), for example, argues that "the radical shifts in housing prices in recent years were caused mainly by investorinduced speculation." Wheaton and Nechayev (2008), using cross-section time series data for a sample of 10 metropolitan markets, find that increases in housing demand related to fundamentals such as population, income growth, and the decline in interest rates could not 
explain the increase in housing prices in the years running up to 2005. Barlevy and Fisher (2011) also present evidence supporting the view that the boom-bust in the housing market was associated with speculative bubbles.

Some researchers, on the other hand, question whether there was widespread ex ante misalignment of house prices during the housing boom (Smith and Smith 2006). However, even without ex ante misalignment of house prices, rapid price gains still could have affected mortgage financing outcomes through expectations of future appreciation. In this regard, other researchers argue that expectations of rising house prices (and an accompanying discounted probability of sizable house price declines) rationalize the decisions of borrowers, investors, and intermediaries during the housing boom (Gerardi et al. 2008, and Foote et al. 2012). In the context of elevated expectations for house price appreciation, reduced sensitivity of take-up rates among mortgage options to components of mortgage interest rates could be consistent with rational consumer choice. In particular, previous research indicates that the differences in the expected tenor of mortgage loans is important to the differential effects of mortgage pricing components, with shorter expected tenors favoring adjustable-rate financing relative to fixed-rate mortgage financing (see for example, Campbell and Cocco (2003)). In this regard, the prospect for future house price appreciation may have been viewed by some homebuyers as providing opportunities for accumulating home equity and potentially refinancing at more favorable terms in a relatively short period of time, reducing the expected tenors of the mortgage loans. ${ }^{2}$

The rest of the paper is organized as follows: Section 2 provides an overview of the changes in house prices and mortgage financing outcomes during the period 2000 to 2007; Section 3 presents a literature review related to mortgage outcomes; Section 4 discusses the empirical methodology used in this study; Section 5 discusses the data used in this study; Section 6 discusses the empirical results; and Section 7 summarizes the main conclusions.

\section{House prices and the selection of mortgage financing during the housing boom}

House price appreciation in the United States began picking up steam in the second part of the 1990s, after lagging gains in rents in the first part of that decade (Figure 1). In the late

\footnotetext{
${ }^{2}$ As pointed out in previous studies, hybrid adjustable-rate mortgage, for example, tend to be paid down (refinanced) ahead of the specified adjustable rate period (see, for example, Demyanyk 2009).
} 
1990s and early 2000s the pace of house price appreciation accelerated, with the increase in one national index averaging about 11 percent at an annual rate over the period 2000 through 2003, outpacing gains in rental rates and pushing up price-to-rent ratios. ${ }^{3}$ In late 2003, the pace of house price appreciation jumped up further, averaging about 17 percent at an annual rate for the 2004 to 2005 period and leaving house price-to-rent ratios at historic highs. House prices peaked in the first part of 2006 and then drifted lower before starting to turn down more sharply in 2007.

The pace of house price appreciation also varied considerably across housing markets. For example, using zip code level data, for the 2004 to 2005 period, the $5^{\text {th }}$ to the $95^{\text {th }}$ percentile range in annual house price appreciation was 0.2 percent to 27.5 percent. $^{4}$ In that period, a zip code in Nye County, Nevada, posted the highest rate of 45.7 percent in 2004. At the other extreme, house prices declined 10.7 percent in a zip code in Cuyahoga County, Ohio in 2004. With regard to the selection of mortgage financing, fixed-rate mortgages traditionally have been the most popular in the United States. For the vast majority of fixed-rate loans, the loan principal is fully amortized (the monthly payment automatically includes both interest and principal repayment). ${ }^{5}$ Since the early 1980 s, however, the mix of fixed-rate and adjustable-rate mortgages has fluctuated. ${ }^{6}$ Figure 2 shows the long history for the share of adjustable-rate loans from Freddie Mac Primary Mortgage Survey along with the adjustable-rate share from the sample drawn from the McDash Analytics data used in this study. ${ }^{7}$ Adjustable-rate mortgages regained popularity starting in the early 2000s. The relative popularity of these loans was especially notable in the period when house price appreciation was the most rapid.

There are different types of adjustable-rate mortgages. One main category is loans for which the principal is fully amortized. Among fully amortized adjustable-rate mortgages (A$\mathrm{ARM}$ ), a basic form is one in which the interest rate on a loan is set as a spread to a reference

\footnotetext{
${ }^{3}$ House price appreciation is based on the CoreLogic house price index for single family homes.

${ }^{4}$ House price appreciation is based on zip-code level data from the CoreLogic house price index for single family homes.

${ }^{5}$ The overwhelming majority of fixed-rate mortgages involve the payment of interest and principal. In the sample for this study about 98 percent of fixed-rate loan payments included principal and interest and 2 percent allowed interest-only payments for a period of time.

${ }^{6}$ U.S. Congress passed the Alternative Mortgage Transactions Parity Act (AMTPA) in 1982, allowing non-federally chartered mortgage lenders to offer adjustable-rate mortgages. Prior to that, lenders were mostly constrained to offer fixed-rate mortgages.

${ }^{7}$ The series from Freddie Mac is for all first lien mortgage applications, while the McDash Analytics data used in this study include only approved first lien mortgages for home purchases. McDash Analytics, LLC is a wholly owned subsidiary of Black Knight Financial Services, LLC.
} 
rate such as the one-year Treasury rate. The interest rate then adjusts periodically with changes in the reference rate, often with limits on the size of the periodic adjustments and the total adjustment over the life of the loan. Another type of adjustable-rate mortgage requiring amortization is the hybrid adjustable-rate mortgage. An example of such a mortgage contract is the so-called 2-28 mortgage, which is a 30-year mortgage where the interest rate remains fixed for two years and adjusts periodically during the remaining years.

Other adjustable-rate mortgage contracts allow for delaying amortization - that is, backloading of principal repayment. Such loans have been referred to as alternative mortgage products (AMPs). ${ }^{8}$ As with A-ARMs, interest rates on AMPs are linked to reference rates. AMPs include option adjustable-rate mortgages, which allow the borrower to choose among several payment options each month. Those options typically include (1) a minimum payment which keeps the loan current (but with negative amortization of unpaid interest), (2) an interest-only payment, and (3) a payment of principal and interest. ${ }^{9}$ Another type of AMP is the interest-only mortgage contracts. As the name indicates, the periodic payments cover only interest charges for a period of time. ${ }^{10}$

\section{Residential Mortgage Financing Selection}

In this section we discuss the determinants of mortgage financing outcomes drawing on previous theoretical and empirical research. Of particular relevance to this study are the relations of mortgage pricing components and house price appreciation to mortgage financing outcomes. The previous literature also highlights various loan and borrower characteristics found to be related to take-up rates among mortgage options. In that regard, a loan feature important for this study is the treatment of amortization of loan principal. As indicated earlier, while principal payments on fixed-rate mortgages typically reflect full amortization, adjustable-rate mortgages are differentiated by the extent to which principal repayment is back-loaded.

\footnotetext{
${ }^{8}$ See Cocco (2013) and Brueckner et al. (2015).

${ }^{9}$ Option adjustable-rate mortgages were introduced in the $1980 \mathrm{~s}$, but gained popularity in the 2000 s, especially in states where home prices were rising rapidly.

${ }^{10}$ After a specified period of time, the borrower may refinance the mortgage, make a lump sum payment, or begin paying off the principal of the loan along with interest payments. In the case of so-called balloon mortgages the principal is due at the end of the contract period.
} 
Other loan characteristics considered in previous studies of mortgage choice include loan size relative to limits set by the government-sponsored enterprises (GSEs) and loan size relative to the value of the purchased property. Borrower characteristics investigated in previous research include credit ratings, borrower attitudes toward risk, variability of income, expected cost of default, degree of financial constraint, and borrower mobility (probability of moving or expected mortgage tenor). ${ }^{11}$

\section{Mortgage Pricing Components}

The empirical literature on mortgage financing outcomes finds that components of mortgage loan pricing play a dominant role in the selection among mortgage options. In terms of specific pricing components, much of the literature on the selection of mortgage financing considers the interest rates on fixed-rate and adjustable-rate mortgages. More recent refinements in modeling have incorporated the underlying components of mortgage interest rates related to interest rate term premiums, expected short-term rates, and risk compensation.

Exemplary of earlier studies using mortgage interest rates, Brueckner and Follain (1988), using borrower (loan) level data for the U.S., and Nothaft and Wang (1992), using aggregated time series data for the U.S. and selected subregions, find that higher interest rates on fixed-rate mortgages tend to lead to higher shares of adjustable-rate mortgage loans. For the pricing of adjustable-rate loans, these studies included the difference between interest rates on fixed-rate versus adjustable-rate loans. The findings show that a larger difference favors the selection of adjustable-rate mortgages. ${ }^{12}$ Subsequent studies using larger data sets covering longer time periods also find a positive relationship of the propensity for borrowers to opt for adjustable-rate financing with the level of interest rates on fixed-rate loans and the difference between interest rates on fixed-rate and those on adjustable-rate loans (Jones and Miller (1995), Coulibaly and Li (2009), Krainer (2010), Moench et al. (2010)).

Refinements in modeling mortgage selection outcomes have been made in recent research. These studies recognize that the components of mortgage interest rates are determined by underlying market conditions and other factors. In particular, interest rates on fixed-rate loans

\footnotetext{
${ }^{11}$ See for example, Campbell and Cocco (2003), Alm and Follain (1987), and Brueckner (1986).

${ }^{12}$ These findings are also supported by results in other earlier work also by Baesel and Biger (1980), Statman (1982) and Dhillon et al. (1987).
} 
are linked to longer-term, credit risk-free interest rates, such as the yield on longer-term Treasury bonds. The longer-run risk-free rates, in turn, reflect expected short-term interest rates and term premiums. ${ }^{13}$ Another component of interest rates on fixed-rate mortgages is the markup, which represents compensation to a lender for bearing various risks, where the risks for a given mortgage can be related to local housing market conditions as well as individual loan and borrower characteristics. The interest rate on a fixed-rate mortgage, then, can be expressed as:

$$
F R_{x, i}=T P_{x}+E\left(S R_{x}\right)+f r m_{x}+\varepsilon_{x, i}
$$

where $F R_{x, i}$ is the interest rate on a fixed-rate for borrower $(i)$ on loan with expected tenor $(x)$, $E\left(S R_{x}\right)$ is the expected short-term interest rates over the expected tenor of the loan, and $T P_{x}$ is the interest rate term premium for the period of expected tenor of the loan. ${ }^{14}$ The term, frm $m_{x}$, is the average markup and, as an average, would reflect general credit supply conditions in the mortgage market. The term, $\varepsilon_{x, i}$, is the net difference in the markup (relative to the average markup) a borrower would face reflecting differences in individual housing markets, loan characteristics, and borrower characteristics.

The expected interest rate on adjustable-rate mortgages also can be broken into components. The mortgage rates are tied to reference rates that typically are shorter-term market interest rates. A markup that represents compensation to a lender for bearing risk also is a component of the interest rate on adjustable-rate mortgages. In general, the expected rate on an adjustable-rate mortgage would be the expected short-term rates over the borrower's expected tenor of the loan and the markup. That is,

$$
E\left(A R_{y, i}\right)=E\left(S R_{y}\right)+a r m_{z}+\gamma_{z, i},
$$

where $E\left(A R_{y, i}\right)$ is the expected mortgage interest rate for borrower (i) with expected loan tenor (y). The term $E\left(S R_{y}\right)$ is the expected short-term rate over the borrower's expected tenor $(y)$ of the loan, which may or may not be equal to $(x)$. Regarding the markup, $\operatorname{arm}_{z}$ is the average markup reflecting the lender's expected tenor $(z)$, which may or may not be the same as that of the borrower's expected tenor of the mortgage loan. The term, $\gamma_{z, i}$, is the difference in the markup for the individual borrower relative to the average markup, again reflecting differences in individual housing markets, loan characteristics, and borrower characteristics.

\footnotetext{
${ }^{13}$ The term premium represents the compensation investors require to have the nominal return on their funds locked in for a period of time instead of being rolled over in a series of shorter-term instruments.

${ }^{14}$ In setting the interest rate on a fixed-rate mortgage, expectations regarding the tenor of a loan would be those of the lender, which may or may not coincide with the borrowers' expectations.
} 
The difference between interest rates on a fixed-rate and an adjustable-rate loan can be expressed as:

$$
F R_{x, i}-E(A R)_{y, i}=T P_{x}+E\left(S R_{x}\right)+f r m_{x}-E\left(S R_{y}\right)-\operatorname{arm}_{z}+\left(\varepsilon_{x, i .}-\gamma_{z, i}\right) .
$$

The term premium, $T P_{x}$, represents the adjustment to the yield on an instrument that investors require to commit to holding a long-term debt instrument instead of a series of shorter-term instruments. From the equation above, a higher term premium increases the rate on a fixed-rate mortgage relative to the initial rate on an adjustable-rate mortgage. Previous research points to at least three channels in which the difference in initial rates could affect mortgage financing outcomes. One is an affordability or borrower-qualification channel. In that regard, Nothaft and Wang (1992) note that one interpretation of the empirical evidence of a positive relation between interest rates on fixed-rate mortgages and the selection of adjustable-rate mortgage financing is that it reflects borrowing constraints. The argument is, at higher interest rates, it is less likely that a borrower with a given income (and down payment) would qualify for a mortgage.

Elliehausen and Hwang (2010) present another potential channel, one in which the slope of the yield curve can influence mortgage selection outcomes due to the preferences of borrowers rather than financial constraints per se. In that model, borrowers are assumed to be less patient than lenders, so that the difference in the interest payment profile affects the selection between fixed-rate and adjustable-rate mortgages. With a higher term premium steepening the yield curve (the payment profile), the model implies a positive relation between the term premium and the take-up rate of adjustable-rate financing. The prediction is consistent with the empirical results in Elliehausen and Hwang (2010). ${ }^{15}$

A third potential channel through which the term premium could affect take-up rates among mortgage financing options is related to differences in expected tenors of mortgage loans (that is, the prepayment or refinancing horizons), rather than differences in time preferences per se. Pertinent here is Campbell and Cocco (2003), who show that borrowers with lower mobility (longer expected tenors of mortgage loans) prefer fixed-rate financing. For a given distribution of

\footnotetext{
${ }^{15}$ In the empirical analysis, Elliehausen and Hwang (2010) include a "term spread," a "rule-of-thumb" term premium estimate used in Koijen et al. (2009), which is positively related to the propensity of borrowers to favor adjustable-rate mortgages.
} 
expected mortgage loan tenors among borrowers, then, a higher term premium would be expected to increase the likelihood that borrowers would opt for adjustable-rate financing.

Koijen et al. (2009) also demonstrate the importance of interest rate term premiums in the selection among mortgage financing options. Their empirical analysis, using macro-level data as well as loan-level data aggregated over several groupings, provides evidence that higher interest rate term premiums increase the likelihood of adjustable-rate financing being selected.

With regard to interest rate expectations, the expected short-term interest rates could affect the selection among mortgage financing options through channels similar to those for the term premium. Expectation of higher future short-term interest rates should boost initial interest rates on fixed-rate mortgages relative to those on adjustable-rate mortgages. Again, to the extent that some borrowers are financially constrained, a boost to interest rates on fixed-rate mortgages relative to initial interest rates on adjustable-rate mortgages could affect take-up rates of those types of mortgages through a borrower-qualification channel. Similarly, in Elliehausen and Hwang (2010), the effect of a steeper slope of expected short-term rates on the payment profile implies a positive relation between the term structure of expected short-term interest rates and the take-up rate of adjustable-rate financing. ${ }^{16}$

The other parallel with the term-premium effect for a relation between the term-structure of expected short-term interest rate and mortgage selection outcomes is related to differences in expected mortgage tenors a la Campbell and Cocco (2003). A steepening of term structure of expected short-term rates would increase $E\left(S R_{x}\right)$ relative to $E\left(S R_{y}\right)$ for borrowers with expected mortgage loan tenors that are shorter than $x$. For a given distribution of expected mortgage loan tenors, then, a steepening of the expected term structure of short-term interest rates would be expected to increase the probability of borrowers using adjustable-rate financing options, all else equal.

Regarding components of the loan markups, $\mathrm{frm}_{x}$ and $\mathrm{arm}_{z}$, they represent averages and should reflect general credit supply conditions in the mortgage market. ${ }^{17}$ The average markups

\footnotetext{
${ }^{16}$ Along with an estimate of the term premium, in their empirical analysis, Elliehausen and Hwang (2010) include an estimate of the yield curve - the difference between the interest-rates on the five-year Treasury yield and the oneyear Treasury yield, which is positively related to the propensity of borrowers to favor adjustable-rate mortgages. Note that the spread reflects both expected short-term interest rates and a term premium.

${ }^{17}$ Elliehausen and Hwang (2010), for example, argue that higher interest rate risk tends to lead a borrower to opt for fixed-rate financing. Higher interest rate volatility increases expected losses for the lender on adjustable-rate mortgages. Accordingly, the lender increases the markup on adjustable-rate mortgages due to concerns about future
} 
on fixed-rate and adjustable-rate mortgages, respectively, are expected to be positively and negatively related to the propensity of borrowers to select adjustable-rate financing. The net differences from the average markups, $\varepsilon_{x, i}$ and $\gamma_{z, i}$, will vary for individual borrowers and depend on conditions in the relevant housing market as well as certain loan and borrower characteristics.

With differences in the treatment of the amortization of loan principal, the sensitivity to mortgage pricing components could differ between A-ARMs and AMPs. For example, Brueckner et al. (2015) maintain that the longer expected holding period for AMPs could mean less influence of the term structure of short-term interest rates on that mortgage outcome relative other adjustable-rate options. The same might hold for the term premium, to the extent that the expected loan tenors of borrowers selecting AMPs are longer.

\section{House Price Appreciation}

Previous research finds a relation between house price appreciation and the selection of mortgage financing options. Increases in house price appreciation are associated with increases in take-up rates of adjustable-rate financing relative to fixed-rate financing, especially for alternative mortgage products. Relevant for adjustable-rate versus fixed-rate mortgage financing outcomes generally, the Elliehausen and Hwang (2010) model predicts that higher expected house price appreciation should increase the likelihood of a borrower opting for adjustable-rate financing. This result is obtained because higher house prices in the future reduce the expected probability of default on adjustable-rate loans and, thus, lower the markup. In terms of the framework presented earlier, with higher house price appreciation, the component of the adjustable-rate markup, $\gamma_{\mathrm{z}, i}$, in the relevant market would be reduced.

In other research, Piskorski and Tchistyi (2011) argue that mortgages with scheduled interest rate increases such as hybrid adjustable-rate mortgages should be prevalent in locations with higher expected house price appreciation. Krainer (2010) presents empirical results indicating that higher house price appreciation is associated with an increase in take-up rates of adjustable-rate financing relative to fixed-rate financing.

In the case of AMPs, Brueckner et al. (2015) show that, when future house-price expectations become more favorable, thus reducing default concerns, mortgage selections shift

defaults owing to borrower "payment shock." This tends to reduce the appeal of adjustable-rate financing for the borrower because the option value of default for the borrower, who is assumed to be less patient, is less than the lender's required adjustment to the markup on an adjustable-rate mortgage. 
toward alternative payment products (those with back-loaded prepayment of principal). This prediction is confirmed by their empirical evidence showing that an increase in past house-price appreciation, which they argue captures more favorable expectations for the future, raises the market share of alternative mortgage products. The LaCour-Little and Yang (2010) model also implies that deferred amortization contracts are more likely to be selected in housing markets with greater expected price appreciation. In Barlevy and Fisher (2011), the emergence of house price bubbles leads both speculators and their lenders to prefer interest-only mortgages to traditional mortgages. Their empirical results indicate that interest-only mortgages were more prevalent in markets of high expected house price appreciation in the period 2001 to 2008.

\section{Interaction between house price appreciation and interest rate-related components.}

From the previous studies, then, mortgage pricing components and house price appreciation appear to be related to the probabilities of different financing options being selected. Central to our analysis is how the pace of house price appreciation might alter the consideration given to interest rate-related components when selecting among mortgage financing options. In our analysis we test for such effects by interacting house price appreciation with mortgage pricing components. At issue is whether the sensitivity of the mortgage financing selections to mortgage pricing components diminishes with an increase in the pace of house price appreciation in a market.

One potential factor behind such a dampening effect could be a general disconnect with fundamental determinants of mortgage selection owing to housing price bubbles. A second is a reduction in the average expected tenor of mortgages. Regarding this second channel, as noted earlier, while expectations regarding house price appreciation during the housing boom may have been too optimistic ex post, given those expectations, a finding that house price appreciation altered the estimated relationship of mortgage pricing components and mortgage selection outcomes still could be consistent with rational consumer choice. In particular, the implications of borrower mobility in Campbell and Cocco (2003) can apply more generally to the expected tenor of a mortgage. One of the motivations, then, for considering the interactive effects of mortgage pricing components and house price appreciation is the potential for the latter to shorten the average expected tenor of mortgages. 
To start, with little or no change in house prices, the expected tenor of a mortgage loan would be tied to expectations such as those related to life-cycle events including illness, retirement, job changes, unemployment, etc. However, that might change to some extent when house prices are rising rapidly. Historically, the past changes in house prices have been good predictors of future changes, so increases in house prices in the first part of the last decade could have fed expectations of further appreciation. The prospects for future appreciation may have been viewed by some borrowers as providing opportunities for accumulating home equity, which could enable them to refinance at more favorable terms (lower interest rate) in a few years, even if the borrower did not plan to move. ${ }^{18}$ Alternatively, some purchasers looking to "flip" houses in markets with high house price appreciation would have had very short expected loan tenors. In both cases, the expected time to paying off mortgages could be shortened in higher house price appreciation markets, leading to higher adjustable-rate mortgage shares for given term premium levels, expected interest rates, and markups.

Similarly, an effective shortening of the average expected tenor of mortgage loans in higher house price appreciation markets could alter the effects of interest rate volatility on mortgage choice. A potential channel is a shorter-than-expected tenor of a mortgage, which would work to reduce the expected length of exposure to interest rate fluctuation and, thus, could mute the consideration some borrowers would give to interest rate volatility.

\section{Other determinants of mortgage selection}

The literature on mortgage selection identifies several other factors that can affect the propensities of borrowers to choose different types of mortgage financing. Differences in the degree of borrower risk aversion generally and the degree of financial constraints for borrowers can be relevant to mortgage financing outcomes. Campbell and Cocco (2003) present a model in which attitudes toward risk and borrowing constraints can affect mortgage choice, with less riskaverse, financially constrained borrowers more likely to opt for adjustable-rate financing. That is consistent with the findings in Coulibaly and Li (2009) that fixed-rate financing is preferred by

\footnotetext{
18 The typical motives for refinancing are to improve financing terms, such as securing a lower interest rate, or to cash out a portion of equity. With expectation of rapidly appreciating house prices, a borrower could expect that an increase in home equity would lower the loan-to-value ratio and allow for refinancing into a loan with a more favorable interest rate in the future.
} 
more risk-averse borrowers, those with more uncertain income, as well as those less likely to move.

Coulibaly and $\mathrm{Li}$ (2009) also find empirical evidence that financially constrained borrowers tend to favor adjustable-rate financing. Observable variables that might be indicative of financial constraints considered in previous research are the ratio of the initial size of a mortgage loan to the appraised value of a property and the ratio of the price of a property to a borrower's income. Koijen et al. (2009) refer to borrower credit risk ratings as one of the welldocumented measures of credit constraint, with a lower credit rating associated with a higher probability of selecting adjustable-rate financing. Two other studies supporting the inclusion of measures of borrower credit ratings in empirical models of mortgage selections are Krainer (2010) and Vickery and Fuster (2015).

With regard to A-ARM and AMP outcomes, Cocco (2013), in a study of U.K. borrowers, finds AMPs were used by households to lower initial mortgage payments and/or to borrow larger amounts relative to their income - that is, higher loan-to-income ratios-compared to fully amortized adjustable-rate mortgages. Similarly, the flexibility in payments for some AMP loans may reduce the sensitivity to interest rate volatility relative to A-ARMs. In addition, the game theoretic model of mortgage contract choice in LaCour-Little and Yang (2010) implies that deferred amortization contracts are more likely to be selected by households with greater risk tolerance.

Finally, whether the size of a loan conforms to the federal GSE size limits may be relevant to mortgage choice. Previous research shows that interest rates on fixed-rate mortgages are lower on loans that conform to those size limits compared with otherwise comparable larger loans (see for example, Passmore et al. 2005). In addition, Vickery (2007) shows that the market share of adjustable-rate mortgages discontinuously jump up for loans at the GSE conforming loan limit. ${ }^{19}$

\section{Empirical Methodology}

We model the mortgage financing outcomes using a multinomial probit model,

$$
P\left(I_{i}=m\right)=P\left(U_{i, m}>U_{i, j}\right), \text { for } m=(1,2,3), j=(1,2,3) \text { and } j \neq m,
$$

\footnotetext{
${ }^{19}$ Vickery and Fuster (2015) address the effect of access to a liquid securitization market for nonconforming loans on the share of fixed-rate mortgage among nonconforming loans.
} 
where $U_{i, m}$ represents the utility for borrower $i$ opting for mortgage type $m$. The options for $m$ are three non-ordered outcomes for mortgage financing: fixed-rate mortgage, adjustable-rate mortgage with full amortization-A-ARMs, and alternative mortgage products-AMPs ${ }^{20}$ Following previous research on the determinants of mortgage financing outcomes, $I_{i}$ is expressed as a function of mortgage pricing components, housing market conditions, and borrower/loan characteristics:

\section{$I_{i}=f($ Mortgage Pricing Components, Housing Market Conditions, Loan/Borrower Characteristics).}

The variables included in each of the three groupings are based on the discussion in the previous section. The general conceptual variables are presented in this section. To focus on the conceptual dimensions the subscripts are dropped. The empirical counterparts to the conceptual variables are defined in the data section that follows.

The variables under mortgage pricing components include:

- $\quad$ Term premium $(T P)$;

- Expected term structure of short-term interest rates (Term_Str);

- Interest rate volatility $\left(R_{-} \_\mathrm{Vol}\right)$;

- Average fixed-rate markup ( $f r m)$; and

- Average adjustable-rate markup ( $\mathrm{arm})$.

From the discussion in the previous section, the term premium (TP) is a direct component of the interest rate on a fixed-rate mortgage. The TP is expected to be positively related to the propensity of borrowers to select adjustable-rate financing in general relative to fixed-rate loans.

The expected term structure of short-term rates (Term_Str) is related to the slope of expected short-term rates. Given a distribution of expected tenors of mortgage loans among homebuyers, a steepening of the slope of expected short-term interest rates would be expected to increase the take-up rate of adjustable-rate mortgages. Interest rate volatility is expected to be positively related to the propensity to select A-ARMs, though not necessarily AMP loans, relative to fixed-rate loans.

\footnotetext{
${ }^{20}$ The model also was estimated with four non-ordered outcomes: fixed-rate mortgages, A-ARMs, option adjustable-rate mortgages and interest-only adjustable-rate mortgages. The findings from that analysis regarding the effects of mortgage pricing components and the interaction of those components with house price appreciation are similar to those present for the estimations based on the three-outcome model.
} 
Regarding loan markups, frm and arm, they represent averages and should reflect general credit supply conditions in the mortgage market. The average markups on fixed-rate and adjustable-rate mortgages, respectively, are expected to be positively and negatively related to the propensity of borrowers to select adjustable-rate financing. Note, the net difference from the average markup for an individual borrower is observable only for the loan selected and not for all the mortgage alternatives considered. That is, for $\varepsilon_{x, i}$ and $\gamma_{z, i}$ in equation 3 , the observation for only one or the other (not both) is available for a given borrower. Thus, these differences from the average markups are not explicitly included in the empirical specification. However, as noted earlier, the net differences in the individual markups for borrowers relative to the average markups should depend on the housing market condition variables as well as various loan and borrower characteristics that are included in the empirical analysis.

Housing market conditions

- House price appreciation (HPI_App)

- Volatility of house price appreciation (HPI_Vol)

Loan and borrower characteristics

- $\quad$ Ratio of loan value to property value (LTV)

- Loan eligibility under GSE loans limits (Conform)

- $\quad$ Borrower credit risk rating (Credit_Risk)

- Ratio of the purchase price of a property to the borrower's income (Pr_Inc)

- Income risk (Inc_Risk)

For housing market conditions, house price appreciation is expected to be positively related to the propensity of borrowers to select adjustable-rate financing relative to fixed-rate financing in general, and AMPs relative to A-ARMs. The central focus of the analysis is the interactive effects of house price appreciation on mortgage pricing components. Based on the early analysis, higher house price appreciation is expected to dampen the estimated sensitivities between mortgage financing choices and the term premium, the term structure of short-term interest rates, interest rate volatility and the risk markups. House price volatility is expected to reduce the relative attractiveness of A-ARMs.

Among the loan and borrower characteristics, the ratio of the size of a loan to the value of the property purchased and the borrower credit risk rating are expected to be positively related to 
the propensity of borrowers to select adjustable-rate mortgages. A loan conforming to GSE loans limits would be expected to favor fixed-rate relative to adjustable-rate financing. A higher ratio of the purchase price of a property to the borrower's income is expected to be positively related to the propensity to select adjustable-rate financing in general and AMPs in particular. Finally, for income risk, higher risk is expected to be associated with higher rates of take-up of adjustable-rate financing.

\section{Data}

The loan level data used in the empirical analysis are from McDash Analytics. The related borrower income data are from the Home Mortgage Disclosure Act (HMDA) databases. The random sample used in the analysis includes over 2.6 million first-lien, 30-year loans for home purchases by the primary resident. ${ }^{21}$ The sample period is from the first quarter of 2000 through the third quarter of 2007. ${ }^{22}$ The loans are grouped by interest rate type and treatment of amortization. Table 1 shows descriptive statistics for the variables used in the analysis. A-ARM represents adjustable rate mortgages that are fully amortized and AMP represents adjustable-rate mortgages that allow backloading of the repayment loan principal.

The term premium $(T P)$ is the 10-year term premium measured along the lines of a "ruleof-thumb" estimate used in Koijen et al. (2009). Specifically, the term premium is the difference between the ten-year Treasury bond constant maturity yields and the three-year average of interest rates on the one-year Treasury bill. The data are averages for the quarter in which a loan was closed. The term structure of expected short-term interest rates (Term_Str) is estimated as the difference between the trailing three-year average of the one-year Treasury rates and the average of the one-year Treasury rate in the quarter a mortgage is closed (see Koijen et al. 2009). Interest rate volatility $\left(R_{-} \mathrm{Vol}\right)$ is the quarterly average of the Merrill Lynch Option Volatility Expectations (MOVE) index. ${ }^{23}$

The average markup on fixed-rate mortgages $(\mathrm{frm})$ is the difference between the quarterly average of the fixed-rate mortgage interest rates from Freddie Mac for 30-year conventional

\footnotetext{
${ }^{21}$ We view a refinancing decision as different from one to purchase a home. Additional factors, such as the interest rate on the previous loan and the type of previous loan, might be important in mortgage refinancing decisions. Thus, we exclude refinanced loans from the sample.

22 The sample period ends in the third quarter 2007 prior the onset of the financial crisis.

23 The index measures the implied volatility in U.S. Treasury markets.
} 
loans and the average of the 10-year Treasury bond constant maturity yields. The average markup for the adjustable rate mortgage $(\mathrm{arm})$ is measured as the difference between the quarterly average of the interest rates for adjustable-rate mortgages (with a one-year Treasury rate as the reference rate) and the quarterly average of the one-year constant maturity Treasury rates. $^{24}$

For the housing market variables, house price appreciation (HPI_App) is the two-year, percent log change of the CoreLogic house price indexes. The observations are the two-year percent log changes through the month prior to the closing quarter of the loans. The volatility of house price appreciation (HPI_Vol) is the standard deviation of the monthly log changes in CoreLogic house price indexes by zip code over the same two-year period.

For the loan characteristic, the loan-to-value ratio $(L T V)$ is the original principal of a loan as a percent of the appraised value of a property. ${ }^{25}$ LTV applies to the first lien. We noted a concentration of LTV at 80 percent. To qualify for a conforming loan without mortgage insurance generally requires a loan-to-value ratio of at least 80 percent on a first lien. A borrower wishing to finance a property with less than a 20 percent down payment might obtain an 80 percent loan-to-value first-lien mortgage and also obtain a second mortgage when purchasing a home. To account for the potential that first liens just meeting the 80 percent limit might involve second mortgages we include a control for loan-to-value ratios on first liens that are exactly 80 percent. The control is $L T V 80$, which equals one if $L T V$ equals 80 percent and zero otherwise.

The variable Conform equals one if the loan amount is less than or equal to the loan limit for GSE qualifying loans and zero otherwise. The credit risk measure, Credit_Risk, is the consumer credit rating from Fair Isaac Credit Organization (FICO). The values of FICO scores range from 300 to 850, and a higher FICO score indicates lower credit risk of a borrower. $P r \_I n c$ is the ratio of appraised value of a property to a borrower's reported income. The appraisal values are from the McDash Analytics database and the data on borrower income are

\footnotetext{
${ }^{24}$ As noted in the previous section, the actual overall markups faced by each borrower are observable only for the type of loan selected.

${ }^{25}$ Elliehausen and Hwang (2010) present a model in which LTV interacts with the term structure of short-term rates and interest rate volatility. In the context of our specification, the relation of Term_Str and $R \_$Vol to mortgage choice could differ for high versus low LTV loans. Note, however, that the results incorporating the controls for high and low loan-to-value mortgages do not change the conclusions from the analysis.
} 
from the HMDA database. ${ }^{26}$ The proxy for income risk, Inc_Risk, is the average county unemployment rate in the closing quarter of a loan.

\section{Empirical Results}

This section presents the probit results for the sample of properties in 50 states and the District of Columbia. ${ }^{27}$ The estimates are for first-lien mortgages for home purchases. The probit estimations control for year-fixed effects and state-fixed effects. Levels of significance are based on robust standard errors clustered on counties. ${ }^{28}$ The probit model is estimated using the full sample and a subsample. The subsample only includes observations for which house price appreciation is less than the $75^{\text {th }}$ percentile of its sample distribution. The estimation using the subsample is a robustness exercise to determine whether results for the full sample are driven by the observations in markets that experienced especially rapid increases in house prices.

\section{Full Sample}

\section{Probit Estimation}

Table 2 presents probit estimates for first-lien mortgages for home purchases for the full sample. The fixed-rate mortgage is the base outcome. The results relating to A-ARMs are presented in the first panel and the results for the AMPs are presented in the second panel.

For the full sample, the loan and borrower characteristic have the expected signs suggested by studies cited earlier and are statistically significant, with one exception. Consistent with previous research, higher loan-to-value ratios and lower credit risk ratings tend to increase take-up rates for adjustable-rate financing. A higher ratio of house price-to-income, intended as a measure of potential financial constraints, also is associated with higher take-up rates of adjustable-rate mortgages and lower take-up rates of fixed-rate mortgages. ${ }^{29}$

\footnotetext{
${ }^{26}$ The borrower income data from the HMDA datasets is matched to the McDash Analytics dataset. The matching logic can be found in an appendix to Rosen (2011). All the observations included in the sample are unique two-way matches from the data sources.

${ }^{27} \mathrm{We}$ also estimated multinomial logit models. Those models generated very similar empirical results.

${ }^{28}$ The sample also was filtered to include only loans with original loan-to-value ratios greater than 10 percent and less than 110 percent. Observations with house price-to-income ratios above the $99^{\text {th }}$ percentile or below the first percentile were dropped. Observations were excluded if the borrower did not report positive income and for those reporting income in top income code.

${ }^{29}$ Based on the probit estimates in Table 2, measured at mean values of right-hand-side variables, a one standard deviation shock to the price-to-income ratio $\left(P r_{-} I n c\right)$ would increase the probability of an AMP outcome by 0.01
} 
Also consistent with earlier cited research, borrowers with mortgage loan values meeting the conforming loan limits set by the GSEs are less likely to select adjustable-rate financing. A higher county unemployment rate, which is included as a proxy for income risk, is associated with a lower propensity to use adjustable-rate financing.

The mortgage pricing components enter on their own and interact with the house price appreciation in the appropriate housing market (zip code). The coefficients without the interaction relate to the effects on the probability of an adjustable-rate financing outcome relative to the fixed-rate option when house price appreciation is zero. Holding house price appreciation at zero, the coefficients on the mortgage pricing components all have expected signs and are statistically significant for A-ARM outcomes. The corresponding coefficients for AMP outcomes also are statistically significant and with the same signs as for the A-ARM counterparts, with the exception of interest rate volatility. For the coefficients that have the same sign for the two adjustable rate outcomes, the magnitudes of the coefficients are larger for A-ARMs, indicating A-ARM selections are more sensitive to those mortgage pricing components.

Looking at the individual pricing components, a higher average markup on adjustablerate mortgages $(\mathrm{arm})$ lowers the probability that a borrower will opt for those mortgages, and a higher average markup on fixed-rate mortgages $(\mathrm{frm})$ increases the likelihood of a borrower selecting an adjustable-rate loan to purchase a house. The other mortgage pricing components also are statistically significant. The coefficients on the term premium $(T P)$ and the term structure of expected short-term rates (Term_Str) are positive for A-ARMs and AMPs.

For interest rate volatility, higher volatility is associated with a lower propensity for borrowers to select A-ARMs, consistent with Campbell and Cocco (2003) and Coulibaly and Li (2009), and Elliehausen and Hwang (2010). In contrast to the A-ARM results, higher interest rate volatility tends to increase the propensity to select AMPs. ${ }^{30}$

Of the two housing market condition indicators, only house price appreciation is statistically significant. Consistent with previous studies, higher house price appreciation is

and reduce that for a fixed-rate outcome by a same magnitude, with a negligible marginal effect on A-ARM choice. The median price-to-income ratio in the sample is 2.5 and the standard deviation is 0.98 .

${ }^{30}$ The difference in the results could reflect the flexibility in payments for some AMP loans, which could reduce risk of default and, thus, have less of an impact on the adjustable-rate markup for AMPs, a la Elliehausen and Hwang (2010). The result also is consistent with LaCour-Little and Yang (2010), in which deferred amortization contracts are more likely to be selected relative to fully amortized loans by borrowers with greater risk tolerance. 
associated with a higher propensity for borrowers to select adjustable-rate financing relative to the fixed-rate option, with the coefficients for A-ARM and AMP loans of similar magnitude. ${ }^{31}$

The results in Table 2 that are central to the contribution of this paper are those related to the interaction of house price appreciation and the mortgage pricing components. The results for A-ARMs in Table 2 reject the hypothesis that house price appreciation does not affect the sensitivity of mortgage financing outcomes to mortgage pricing components. In particular, for each of the four statistically significant interactions, the interactive effect (shown in the shaded column) dampens the sensitivity of mortgage outcomes to the mortgage pricing component.

For AMP loans, the interaction with house price appreciation also tends to dampen the sensitivity of mortgage outcomes to some of the mortgage pricing components, though less consistently and with less precisely estimated coefficients. One of the interactive effects that is statistically significant and dampens the sensitivity of AMP outcomes is that with the average fixed-rate markup. The coefficients on the interaction of house price appreciation with average adjustable-rate markup and interest rate volatility also indicate an offsetting effect for those two mortgage pricing components for the AMP outcome, though the coefficient on the average adjustable rate is not statistically significant.

\section{$\underline{\text { Marginal effects }}$}

To assess the magnitude of the effects of the mortgage pricing components and those related to the interaction of house price appreciation on the probability of the three financing outcomes, marginal effects can be derived from the probit estimation. For the full sample, the marginal effects are presented in Table 3 for each of the mortgage financing choices. In the first column of each panel, the house price appreciation is set to zero and the effects are scaled by the standard deviations of the independent variables for which the marginal effects are computed. The results in the second column of each panel are the estimates of the marginal effects from the interaction of house price appreciation and the mortgage pricing components. The marginal effects from the interaction are calculated at the sample mean of house price appreciation and scaled by the standard deviation of the variable for which the marginal effect is calculated and

\footnotetext{
${ }^{31}$ Since house price appreciation interacts with the mortgage pricing components, the results in Table 2 for house price appreciation are for when those components equal zero. The net effect of house price appreciation on mortgage choice taking into account the interactions is discussed below.
} 
the mean of house price appreciation. In the third column of each panel, the net effects are the sum of the effects in the first and second columns.

Comparing the first columns of the panels in Table 3, the magnitudes of the marginal effects indicate that the mortgage pricing components primarily differentiate between fixed-rate mortgages and A-ARMs. For those two mortgage outcomes, the marginal effects are economically and statistically significant, of opposite signs, and with similar magnitudes. In the case of the average adjustable-rate markup, for example, with zero house price appreciation, a one standard deviation ( 0.83 percentage point) increase would increase the probability of a fixedrate financing outcome by an estimated 0.17 and reduce the probability of an A-ARM outcome by that same magnitude. ${ }^{32}$ Similarly, in terms of the marginal effects, the average fixed-rate markup and the term structure of short-term interest rates are material for the fixed-rate versus A-ARM outcomes. The marginal effect of interest rate volatility is very small and statistically significant only at the 10 percent level.

For the AMP outcome, the marginal effect of the term structure of short-term interest rates is statistically significant and negative, though smaller in magnitude relative to the effect for the A-ARM outcome. ${ }^{33}$ The marginal effect of interest rate volatility for the AMP outcome is positive and statistically significant but very small in magnitude.

For the interaction effects, estimates of the effects from the interaction of the mortgage pricing components with house price appreciation on the probabilities of the mortgage outcomes are reported in the second columns of the panels in Table 3. As noted, the effects are for onestandard deviation changes in the mortgage pricing components at the sample mean of house price appreciation. The results show that, for A-ARMs, higher house price appreciation consistently dampened the sensitivity of the mortgage pricing components. The marginal effects associated with the interactions with house price appreciation are all statistically significant. In addition, the magnitudes are material, with the offsets ranging from about one-fifth to one-third of the marginal effects when holding house price appreciation at zero.

\footnotetext{
32 The probability of an individual borrower selecting a particular financing option ranges from zero to one.

${ }^{33}$ Note also that the magnitude of the negative marginal effect of expected term structure of short-term interest for the AMP outcome is substantially smaller than that of the negative marginal effect for the fixed-rate outcome. That is, in the two-way comparison between the fixed-rate outcome and the AMP outcome, an increase in the expected term structure of short-term interest rates reduces the probability of fixed-rate mortgages being selected relative to AMPs, which is indicated by the positive coefficient on the expected term structure of short-term interest rates for the AMP outcome in Table 2.
} 
Most of the offsets from dampening effects from the interactions with house price appreciation for A-ARM outcomes are mirrored by those for fixed-rate mortgages. One exception is interest rate volatility. The effects from the interaction with house price appreciation are positive for fixed-rate mortgage and A-ARM outcomes, amplifying the effect in the case of fixed-rate mortgages and dampening it for A-ARMs. The corresponding reduction in marginal effects associated with the interaction with house price appreciation is accounted for by a negative impact related to the AMP outcome.

The third columns of the panels in Table 3 show results for the net effects of the mortgage pricing components, taking into account the interactions with house price appreciations. Even with the dampening effect of house price appreciation on mortgage choices, the fixed-rate mortgage and A-ARM outcomes remain sensitive to mortgage pricing components. On the other hand, AMP outcomes in the full sample are relatively insensitive to the individual pricing components.

To summarize, the results on the marginal effects for the full sample point to three findings. First, mortgage pricing components were significant determinants of fixed-rate mortgages and A-ARM choices, but less so for borrowers selecting AMPs. Second, higher house price appreciation tended to dampen the sensitivity of mortgage outcomes to mortgage pricing terms, though primarily for fixed-rate mortgages and A-ARMs, rather than AMPs. Third, even with the dampening effect of house price appreciation, mortgage outcomes for fixed-rate mortgages and A-ARMs remain sensitive to mortgage pricing terms, with AMP outcomes remaining relatively insensitive.

\section{Lower house price appreciation sample}

As indicated earlier, the pace of house price appreciation varied over time and across markets. This section assesses the extent to which results for the full sample were driven by observations for which house price appreciation was exceptionally high. For the analysis, the probit model specification used for the full sample is estimated using only observations for which house price appreciation is below the $75^{\text {th }}$ percentile of the sample distributions.

The probit estimation results for the subsample presented in Table 4 are consistent with those reported in Table 2. The loan and borrower characteristics have the expected signs suggested by studies cited earlier and are statistically significant, with the exception of the 
measure of income risk which is not statistically significant. For the mortgage pricing components, when holding house price appreciation at zero, the coefficients are statistically significant for A-ARMs and for AMPs, with the same signs for the full sample. The results for house price appreciation for the subsample also are in line with those for full sample.

Regarding the interaction of house price appreciation with the mortgage pricing components, for A-ARM outcomes, the interactive effects are statistically significant and tend to dampen the sensitivity of mortgage outcomes to the mortgage pricing component. However, in Table 4 the magnitudes of the coefficients on the interaction terms tend to be smaller and estimated less precisely compared with the results for the full sample. For AMP loans, only the coefficient on the interaction with house price appreciation and the average fixed-rate markup is statistically significant.

The marginal effects of the mortgage pricing components for the subsample are reported in Table 5. For the lower house price appreciation sample, the mortgage pricing components primarily differentiate between fixed-rate mortgages and A-ARMs, similar to the results for the full sample. Again, for fixed-rate mortgage and A-ARM choices, the marginal effects are statistically significant, of opposite signs, and with similar magnitudes. However, the magnitudes of the dampening effects from the interaction of house price appreciation with the mortgage pricing components are smaller relative to those for the full sample results, ranging from about one-tenth to about one-fourth of the marginal effects when holding house price appreciation at zero. ${ }^{34}$ For AMPs, only the marginal effect of the interaction of house price appreciation with the average fixed-rate markup indicates a statistically significant, though small, dampening effect.

The results for the subsample indicate that findings for full sample results are not driven solely by the observations in markets with exceptionally high rates of house price appreciation. In particular, for the subsample, the dampening effects related to the interaction of house price appreciation with the mortgage pricing component were statistically significant for the fixed-rate mortgage and A-ARM outcomes. However, the results for the two samples do indicate that the observations for the markets with exceptionally higher house price appreciation tend to

\footnotetext{
${ }^{34}$ About two-thirds of the difference in the magnitudes of the estimated marginal effects related to the interactions with house price appreciation reflects the differences in the scaling factors (house price appreciation and the standard deviation of house price appreciation) between the two samples.
} 
accentuate to some extent the dampening effects from the interactions with house price appreciations on the sensitivity of mortgage choices to mortgage pricing components.

\section{House price appreciation}

This section focuses on the effects of house price appreciation itself, with and without interactions with the mortgage pricing components. Consistent with previous research, the probit estimates reported in Table 2 and Table 4 indicate that higher house price appreciation is associated with higher take-up rates of adjustable-rate financing. In the tables, the coefficients on house price appreciation are statistically significant and similar in magnitude for A-ARM and AMP outcomes. Those estimates, however do not take into account the interactions of house price appreciation with the mortgage pricing components. The results discussed in this section show that, when the interactions are taken into account, it turns out that house price appreciation had relatively little additional effect on the mortgage financing choices.

The marginal effects of house price appreciation on the probabilities of the three financing outcomes are presented in Table 6. In the first panel of the table, the marginal effects are derived from the probit estimation results presented in Table 2 and are evaluated at the mean of house price appreciation for the full sample. In the second panel, the marginal effects are derived from the probit estimation results presented in Table 4 and are evaluated at the mean of house price appreciation for the observations below the 75th percentile of the variable.

The first column of each panel shows the marginal effects on each of the three mortgage financing outcomes with the mortgage pricing components set to zero and scaled by the standard deviation of house price appreciation for the respective sample. In both panels, house price appreciation has statistically significant effects on the mortgage choice outcomes. In the first panel, for the full sample, a one standard deviation increase in house price appreciation would reduce the probability of a fixed-rate outcome by 0.16 , with corresponding increases of 0.07 and 0.09 for A-ARM and AMP outcomes, respectively. In the second panel, the negative marginal effects of house price appreciation on the fixed-rate outcome are still notable, though about half the magnitude of the effect in the first panel. For the adjustable-rate outcomes, the marginal effects in the first column of the second panel are about equal. 
The second column of each panel of Table 6 reports the estimates of the remaining marginal effects of house price appreciation of mortgage financing outcomes after taking into account the interactions with the mortgage price components. Again the marginal effects are scaled by the standard deviation of house price appreciation for the respective samples. In the table, the remaining marginal effects are statistically significant for the fixed-rate and A-ARM outcomes for the full sample, but only for A-ARM outcomes for the sample with observations for which house price appreciation is below the 75th percentile of its distribution. However, in both panels, the remaining marginal effects of house price appreciation taking into account the interaction with the mortgage pricing components is quite small. Those results indicate that nearly all of the marginal effects on mortgage choice outcomes associated with house price appreciation can be accounted for by the dampening effects of appreciation on the sensitivities of mortgage outcomes to the mortgage pricing components.

\section{Conclusion}

This study examines the interactive effect of house price appreciation and mortgage pricing components on mortgage selection. The focus is on the period from 2000 to 2007, an episode marked by rapid house price appreciation along with a persistent and notable increase in the use of adjustable-rate mortgage financing, including alternative mortgage products. The analysis considers three non-ordered outcomes: fixed-rate mortgages, fully amortized adjustable rate mortgages (A-ARM), and adjustable rate mortgages that back-load repayment of the loan principal. The latter includes option (payment) and interest-only adjustable-rate mortgages, or so-called alternative mortgage payments (AMP).

The analysis confirms previous research findings that higher house price appreciation is associated with significantly higher take-up rates of adjustable-rate financing. The analysis also shows that mortgage pricing components such as interest rate term premiums, the term structure of expected short-term rates, and markups are important determinants of mortgage borrowers' financing outcomes. In particular, mortgage pricing components primarily differentiate between fixed-rate mortgages and A-ARMs, with AMP outcomes showing relatively little sensitivity to the pricing components.

Going beyond the previous research, the analysis in this study highlights two key findings. First, central to our analysis is how the pace of house price appreciation might alter the consideration borrowers give to interest-rate-related components when choosing the type of 
mortgage financing. The empirical analysis shows that higher house price appreciation is associated with statistically significant and material dampening effects on the sensitivity of mortgage outcomes to mortgage pricing terms. The results, which are especially robust for fixedrate and adjustable-rate outcomes that are fully amortized, are not driven solely by observations in markets with especially high rates of house price appreciation. The latter, however, did accentuate to some extent the dampening effects.

Taking into account the interaction effects also is potentially important to assessing the nature of the effects of house price appreciation on mortgage choice. In particular, the second finding highlighted in the paper is that nearly all of the marginal effects of house price appreciation on mortgage outcomes can be accounted for by the dampening effects of appreciation on the sensitivities of mortgage financing outcomes to the mortgage pricing components. That is, after taking into account the interactive effects with mortgage pricing components, house price appreciation is estimated to have had relatively little additional effect on the mortgage financing choices. 


\section{References}

Alm, James R., and James R. Follain. 1987. "Consumer Demand for Adjustable-Rate Mortgages." Housing Finance Review, 6 (Spring 1987):1-6.

Baesel, Jerome B., and Nahum Biger. 1980. "The Allocation of Risk: Some Implications of Fixed vs. Index-Linked Mortgages." Journal of Financial and Quantitative Analysis, 15 (June 1980): 457-68.

Barlevy, Gadi and Jonas D.M. Fisher. 2011. "Mortgage Choices and Housing Speculation." Federal Reserve Bank of Chicago Working Paper, 2010-12 (revised 2011).

Brueckner, Jan K. 1986. "The Pricing of Interest Rate Caps and Consumer Choice in the Market for Adjustable Rate Mortgages.” Housing Finance Review, 16 (Fall 1986):119-136.

Brueckner, Jan K., Paul S. Calem, and Leonard I. Nakamura. 2015. "House Price Expectations, Alternative Mortgage Products, and Default." Working Paper, No. 15-01. Federal Reserve Bank of Philadelphia.

Brueckner, Jan K. and James R. Follain. 1988. "The Rise and Fall of the Arm: An Econometric Analysis of Mortgage Choice." The Review of Economics and Statistics, 70(1): 93-102.

Campbell, John Y., and Joao F. Cocco. 2003. "Household Risk Management and Optimal Mortgage Choice.” Quarterly Journal of Economics, 118(4): 1,449-1,494.

Cocco, Joao F. 2013. "Evidence on the Benefits of Alternative Mortgage Products." The Journal of Finance, LXVIII (4):1663-1690.

Coulibaly, Brahima, and Geng Li (2009). "Choice of Mortgage Contracts: Evidence from the Survey of Consumer Finances.” Real Estate Economics, 37(4): 659-673.

Demyanyk, Yilia. 2009. "Ten Myths About Subprime Mortgages.” Federal Reserve Bank of Cleveland Economic Commentary, July, 2009.

Dhillon, Upinder S., James D. Shilling, and C.F. Sirmans. 1987. "Choosing Between Fixed and Adjustable Rate Mortgages: Note.” Journal of Money, Credit and Banking, 19(2): 260-267.

Elliehausen, Gregory and Min Hwang. 2010. "Mortgage Contract Choice in Subprime Mortgage Markets." Federal Reserve Board Finance and Economics Discussion Series, 2010-53.

Foote, Christopher L., Kristopher S. Gerardi, and Paul S. Willen. 2012. "Why Did So Many People Make So Many Ex Post Bad Decisions? The Causes of the Foreclosure Crisis." Federal Reserve Bank of Boston Working Paper, 12-2.

Gerardi, Kristopher, Andreas Lehnert, Shane M. Sherlund, and Paul S. Willen. 2008. "Making Sense of the Subprime Crisis." Brookings Papers on Economic Activity 2: 69-145. 
Jones, Steven T. and Norman G. Miller. 1995. "Residential Mortgagee Choice: Does the Supply Side Matter.” Journal of Housing Economics, 4: 71-90.

Koijen, Ralph, Otto Van Hemert, and Stijn Van Nieuwerburgh. 2009. "Mortgage Timing." Journal of Financial Economics, 93(2): 292-324.

Krainer, John. 2010. "Mortgage Choice and the Pricing of Fixed-Rate and Adjustable-Rate Mortgages." FRBSF Economic Letter, 2010-03.

LaCour-Little, Michael and Jing Yang. 2010. "Pay Me Now or Pay Me Later: Alternative Mortgage Products and the Mortgage Crisis.” Real Estate Economics, 28(4): 687-732.

Moench, Emanuel, James Vickery, and Diego Aragon. 2010. "Why is the Market Share of Adjustable-Rate Mortgages So Low?” Federal Reserve Bank of NY Current Issues, 16(8).

Nothaft, E. Frank and H.K. George Wang. 1992. "Determinants of the ARM Share of National and Regional Lending." Journal of Real Estate Finance and Economics, 5(2): 219-234.

Passmore, Wayne, Shane M. Sherlund, and Gillian Burgess. 2005. "The Effect of Housing Government-Sponsored Enterprises on Mortgage Rates.” Real Estate Economics, 33(3): 427 463.

Piskorski, Tomasz, and Alexei Tchistyi. 2011. "Stochastic House Appreciation and Optimal Mortgage Lending.” Review of Financial Studies, 24(5):1407-1446.

Rosen, Richard J. 2011. "Competition in Mortgage Markets: The Effect of Lender Type on Loan Characteristics.” Economic Perspectives, Federal Reserve Bank of Chicago, 35(1): 2-21.

Shiller, Robert J. 2013. "Before Housing Bubbles, There Was Land Fever." New York Times, Economic View. April 20, 2013. http://www.nytimes.com/2013/04/21/business/beforehousing-bubbles-there-was-land-fever.html?ref=business\&_r=1.

Smith, Margaret Hwang and Gary Smith. 2006. "Bubble, Bubble, Where's the Housing Bubble." Brookings Papers on Economic Activity, 1, 2006.

Statman, Meir. 1982. "Fixed or Index-Linked Mortgages from the Borrower's Point of View: A Note." Journal of Financial and Quantitative Analysis, 17(3): 451-57.

Vickery, James. 2007. "Interest Rates and Consumer Choice in the Residential Mortgage Market." Federal Reserve Bank of New York. Memo.

Vickery, James, and Andreas Fuster, 2015. "Securitization and the Fixed-Rate Mortgage." Review of Financial Studies, 2015, 28(1): 176-211.

Wheaton, W. C. and G. Nechayev. 2008. "The 1998-2005 Housing 'Bubble' and the Current 'Correction': What's Different this Time?" Journal of Real Estate Research, 30(1): 1-26. 

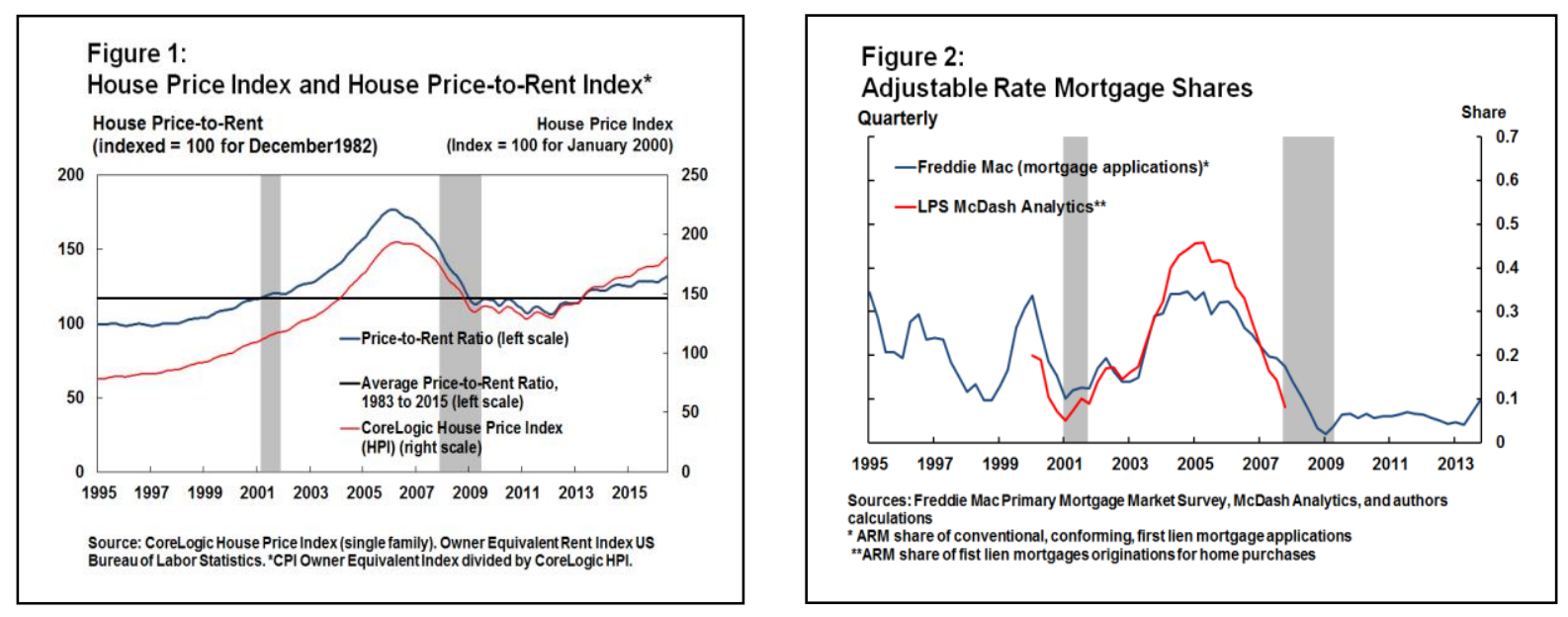

\begin{tabular}{|c|c|c|c|c|c|c|c|c|c|}
\hline \multirow[b]{2}{*}{ Year } & \multicolumn{4}{|c|}{ Mortgage Type } & \multicolumn{5}{|c|}{ Mortgage Pricing Components } \\
\hline & $\begin{array}{c}\text { FRM } \\
\text { (share) }\end{array}$ & $\begin{array}{c}\text { ARM } \\
\text { (share) }\end{array}$ & $\begin{array}{l}\text { A-ARM } \\
\text { (share) }\end{array}$ & $\begin{array}{c}\text { AMP } \\
\text { (share) }\end{array}$ & $\begin{array}{c}\text { arm } \\
\text { markup } \\
\text { (ppt) }\end{array}$ & $\begin{array}{c}\text { frm } \\
\text { markup } \\
\text { (ppt) }\end{array}$ & $\begin{array}{c}\text { TP } \\
\text { (ppt) }\end{array}$ & $\begin{array}{c}\text { Term_Str } \\
\text { (ppt) }\end{array}$ & $\begin{array}{l}\text { R_Vol } \\
\text { (bps) }\end{array}$ \\
\hline $\begin{array}{l}2000 \text { Mean } \\
\text { Std Dev }\end{array}$ & $\begin{array}{l}0.849 \\
0.358\end{array}$ & $\begin{array}{l}0.151 \\
0.358\end{array}$ & $\begin{array}{l}0.117 \\
0.322\end{array}$ & $\begin{array}{l}0.034 \\
0.181\end{array}$ & $\begin{array}{l}0.976 \\
0.285\end{array}$ & $\begin{array}{l}2.057 \\
0.133\end{array}$ & $\begin{array}{l}0.641 \\
0.363\end{array}$ & $\begin{array}{c}-0.756 \\
0.166\end{array}$ & $\begin{array}{l}95.001 \\
8.338\end{array}$ \\
\hline $\begin{array}{l}2001 \text { Mean } \\
\text { Std Dev }\end{array}$ & $\begin{array}{l}0.889 \\
0.314\end{array}$ & $\begin{array}{l}0.111 \\
0.314\end{array}$ & $\begin{array}{l}0.091 \\
0.287\end{array}$ & $\begin{array}{l}0.020 \\
0.141\end{array}$ & $\begin{array}{l}2.373 \\
0.393\end{array}$ & $\begin{array}{l}1.952 \\
0.060\end{array}$ & $\begin{array}{l}-0.147 \\
0.113\end{array}$ & $\begin{array}{l}1.757 \\
0.653\end{array}$ & $\begin{array}{c}110.260 \\
11.096\end{array}$ \\
\hline $\begin{array}{l}2002 \text { Mean } \\
\text { Std Dev }\end{array}$ & $\begin{array}{l}0.781 \\
0.413\end{array}$ & $\begin{array}{l}0.219 \\
0.413\end{array}$ & $\begin{array}{l}0.170 \\
0.375\end{array}$ & $\begin{array}{l}0.049 \\
0.216\end{array}$ & $\begin{array}{l}2.603 \\
0.105\end{array}$ & $\begin{array}{l}1.935 \\
0.143\end{array}$ & $\begin{array}{l}0.190 \\
0.240\end{array}$ & $\begin{array}{l}2.399 \\
0.109\end{array}$ & $\begin{array}{c}123.736 \\
10.980\end{array}$ \\
\hline $\begin{array}{l}2003 \text { Mean } \\
\text { Std Dev }\end{array}$ & $\begin{array}{l}0.721 \\
0.449\end{array}$ & $\begin{array}{l}0.279 \\
0.449\end{array}$ & $\begin{array}{l}0.206 \\
0.404\end{array}$ & $\begin{array}{l}0.074 \\
0.261\end{array}$ & $\begin{array}{l}2.506 \\
0.039\end{array}$ & $\begin{array}{l}1.798 \\
0.106\end{array}$ & $\begin{array}{l}1.100 \\
0.657\end{array}$ & $\begin{array}{l}1.688 \\
0.444\end{array}$ & $\begin{array}{c}113.643 \\
8.975\end{array}$ \\
\hline $\begin{array}{l}2004 \text { Mean } \\
\text { Std Dev }\end{array}$ & $\begin{array}{l}0.547 \\
0.498\end{array}$ & $\begin{array}{l}0.453 \\
0.498\end{array}$ & $\begin{array}{l}0.262 \\
0.440\end{array}$ & $\begin{array}{l}0.191 \\
0.393\end{array}$ & $\begin{array}{l}1.993 \\
0.226\end{array}$ & $\begin{array}{l}1.565 \\
0.025\end{array}$ & $\begin{array}{l}2.495 \\
0.272\end{array}$ & $\begin{array}{l}-0.117 \\
0.542\end{array}$ & $\begin{array}{c}99.754 \\
8.321\end{array}$ \\
\hline $\begin{array}{l}2005 \text { Mean } \\
\text { Std Dev }\end{array}$ & $\begin{array}{l}0.536 \\
0.499\end{array}$ & $\begin{array}{l}0.464 \\
0.499\end{array}$ & $\begin{array}{l}0.188 \\
0.390\end{array}$ & $\begin{array}{l}0.277 \\
0.447\end{array}$ & $\begin{array}{l}0.850 \\
0.148\end{array}$ & $\begin{array}{l}1.578 \\
0.093\end{array}$ & $\begin{array}{l}2.348 \\
0.102\end{array}$ & $\begin{array}{c}-1.708 \\
0.291\end{array}$ & $\begin{array}{c}78.436 \\
2.817\end{array}$ \\
\hline $\begin{array}{l}2006 \text { Mean } \\
\text { Std Dev }\end{array}$ & $\begin{array}{l}0.626 \\
0.484\end{array}$ & $\begin{array}{l}0.374 \\
0.484\end{array}$ & $\begin{array}{l}0.147 \\
0.354\end{array}$ & $\begin{array}{l}0.228 \\
0.419\end{array}$ & $\begin{array}{l}0.602 \\
0.058\end{array}$ & $\begin{array}{l}1.614 \\
0.061\end{array}$ & $\begin{array}{l}1.923 \\
0.400\end{array}$ & $\begin{array}{l}-2.050 \\
0.252\end{array}$ & $\begin{array}{c}64.780 \\
2.125\end{array}$ \\
\hline $\begin{array}{l}2007 \text { Mean } \\
\text { Std Dev }\end{array}$ & $\begin{array}{l}0.782 \\
0.413\end{array}$ & $\begin{array}{l}0.218 \\
0.413\end{array}$ & $\begin{array}{l}0.057 \\
0.232\end{array}$ & $\begin{array}{l}0.161 \\
0.367\end{array}$ & $\begin{array}{l}0.767 \\
0.298\end{array}$ & $\begin{array}{l}1.633 \\
0.140\end{array}$ & $\begin{array}{l}0.781 \\
0.195\end{array}$ & $\begin{array}{l}-0.830 \\
0.406\end{array}$ & $\begin{array}{l}75.927 \\
17.218\end{array}$ \\
\hline $\begin{array}{l}\text { Mean } \\
\text { Std Dev }\end{array}$ & $\begin{array}{l}0.672 \\
0.469\end{array}$ & $\begin{array}{l}0.328 \\
0.469\end{array}$ & $\begin{array}{l}0.169 \\
0.374\end{array}$ & $\begin{array}{l}0.159 \\
0.366\end{array}$ & $\begin{array}{l}1.509 \\
0.828\end{array}$ & $\begin{array}{l}1.704 \\
0.185\end{array}$ & $\begin{array}{l}1.475 \\
0.962\end{array}$ & $\begin{array}{c}-0.229 \\
1.623\end{array}$ & $\begin{array}{l}91.829 \\
21.619\end{array}$ \\
\hline
\end{tabular}

Sources: Loan related data are from McDash Analytics. FRM refers to fixed-rate mortgages. ARM refers to all adjustable-rate mortgages. A-ARM refers to fully amortized adjustable-rate mortgages. AMP refers to alternative mortgage products, which include interest only and option adjustable-rate mortgages that allow for backloading of principal repayment. The sample includes 30-year conventional, first-lien mortgages for home purchases by primary residents. The adjustable-rate markup (arm) is the difference between the interest rate for adjustable-rate mortgages with a one-year Treasury interest rate as the reference rate and the oneyear constant maturity Treasury rate. The fixed-rate markup (frm) is the difference between the interest rate on the 30-year fixedrate conventional mortgages and the ten-year constant maturity Treasury rate. The interest rate term premium (TP) is the difference between the ten-year constant maturity Treasury rate and the trailing three-year average of the one-year constant maturity Treasury rate. The term structure of expected short-term interest rates (Term_Str) is the difference between the three-year average of the one-year constant maturity Treasury rate and the one-year constant maturity Treasury rate. Interest rate volatility (R_Vol) is the Merrill Lynch Option Volatility Expectations index (MOVE). Data for 2007 are based on the first three quarters of the year. 


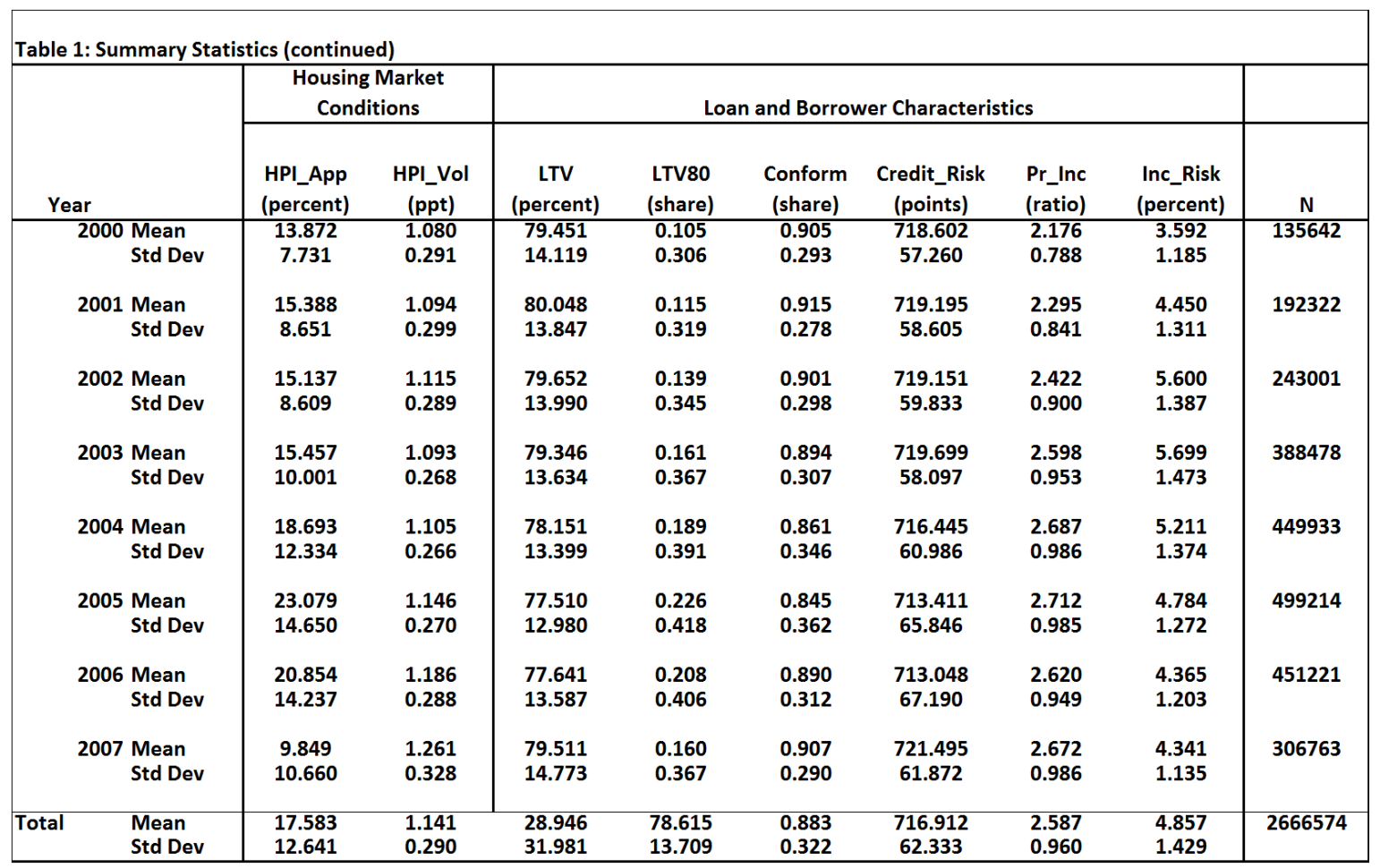

Sources: Loan related data are from McDash Analytics. Borrower income data are from the Home Mortgage Disclosure Act (HMDA) databases. House price indexes are the CoreLogic house price indexes for single family homes by zip code.

HPI_App refers to house price appreciation and is the two-year log percent change in the CoreLogic house price indexes by zip code. HPI_Vol refers to house price volatility and is the standard deviation of the monthly percent log changes over for a two-year period in the CoreLogic house price indexes by zip code. LTV refers to the loan-to-value ratio and is the original loan principal as a percent of the appraised value of the purchased property. LTV80 equals one if LTV $=\mathbf{8 0}$ percent and zero otherwise. Conform equals one if the loan amount is less than or equal the loan limits for GSE qualifying loans and zero otherwise. Credit_Risk is the consumer credit rating from Fair Isaac Credit Organization (FICO). Pr_Inc refers to the price-to-income ratio and is the ratio of the appraised value of a property to a borrower's reported income. Inc_Risk refers to income risk and is the county unemployment rate. Data for 2007 are for the first three quarters of the year. 
Table 2. Mortgage Selection Outcomes: Multinomial Probit Mode

Sample

Sample Period (2000q1 to 2007q3)

${ }^{*}, * *$, and $* * *$ denote significance at the 10,5 and 1 percent levels respectively

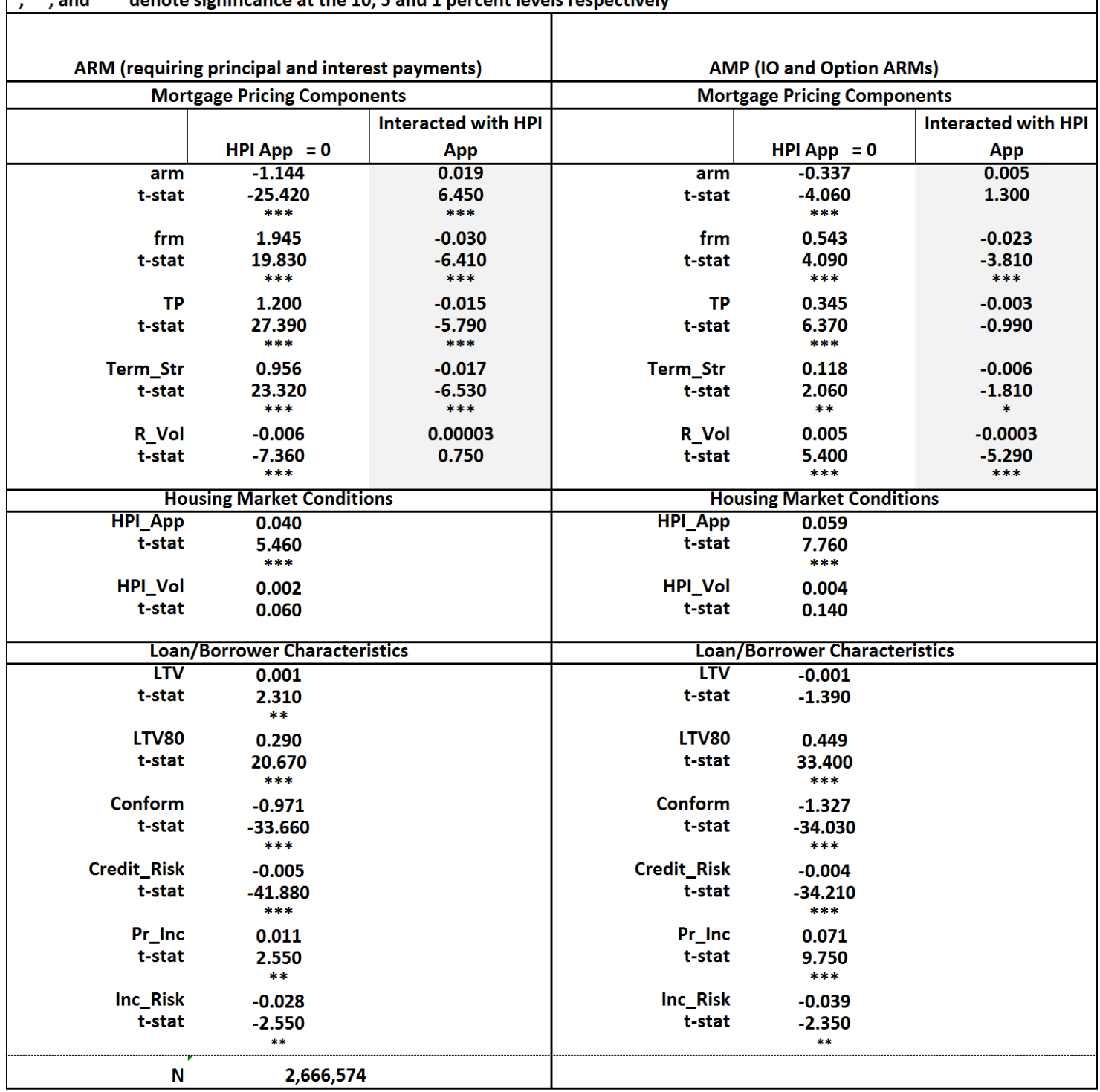

Sources: Loan related data are from McDash Analytics. Borrower income data are from the Home Mortgage Disclosure Act (HMDA) databases. House price indexes are the CoreLogic house price indexes for single family homes by zip code.

The model is a multinomial probit with three non-ordered outcomes for mortgage financing: fixed-rate mortgages; adjustablerate mortgages requiring interest and principal payments (A-ARM); and alternative adjustable-rate mortgages with back-loading of repayment of principal (AMP), which include interest-only (IO) option adjustable-rate mortgages. The observations for the types of mortgages are loan-level. The loans are first-liens for home purchases by primary occupants. The probit estimations control for year-fixed effects and state-fixed effects. Levels of significance are based on robust standard errors clustered on counties. The sample also was filtered to include only loans with original loan-to-value ratios greater than 10 percent and less than 110 percent. Observations with house-price-to-income ratios above the 99th percentile or below the first percentile were dropped. Observations were excluded if the borrower did not report positive income and for those reporting income in top income code. The mortgage pricing components are averages for the quarter in which a loan was closed. Variable definitions are provided in Table 1. 
Table 3. Marginal Effects on Probabilities of Mortgage Selection Outcomes: Full Sample Mortgage Pricing Components

Sample Period (2000q1 to 2007q3) Number of observations $(2,666,574)$

$*, * *$, and $* *$ denote significance at the 10,5 and 1 percent levels, respectively

\begin{tabular}{|c|c|c|c|c|c|c|c|c|c|}
\hline & \multicolumn{3}{|c|}{ Fixed-Rate Mortgage } & \multicolumn{3}{|c|}{$\begin{array}{c}\text { A-ARM } \\
\text { (requiring principal and interest } \\
\text { payments) }\end{array}$} & \multicolumn{3}{|c|}{ and Option ARM) } \\
\hline $\begin{array}{c}\text { Mortgage } \\
\text { Pricing } \\
\text { Components } \\
\end{array}$ & $\begin{array}{c}\text { HPI_App } \\
\text { equal to zero }\end{array}$ & $\begin{array}{l}\text { HPI_App } \\
\text { at sample } \\
\text { mean }\end{array}$ & $\begin{array}{l}\text { Net } \\
\text { HPI_App } \\
\text { at sample } \\
\text { mean }\end{array}$ & $\begin{array}{c}\text { HPI_App } \\
\text { equal to zero }\end{array}$ & $\begin{array}{l}\text { HPI_App } \\
\text { at sample } \\
\text { mean }\end{array}$ & $\begin{array}{l}\text { Net } \\
\text { HPI_App } \\
\text { at sample } \\
\text { mean }\end{array}$ & $\begin{array}{c}\text { HPI_App } \\
\text { equal to zero }\end{array}$ & $\begin{array}{l}\text { HPI_App } \\
\text { at sample } \\
\text { mean }\end{array}$ & $\begin{array}{l}\text { Net } \\
\text { HPI_App } \\
\text { at sample } \\
\text { mean }\end{array}$ \\
\hline$\underset{\text { t-stat }}{\text { arm }}$ & $\begin{array}{c}0.173 \\
19.810 \\
\div \div \div\end{array}$ & $\begin{array}{l}-\mathbf{0 . 0 4 9} \\
-\mathbf{5 . 2 5 0} \\
\neq \neq *+\end{array}$ & $\begin{array}{c}0.124 \\
23.450 \\
\forall \neq ⿻ \neq\end{array}$ & $\begin{array}{c}-0.169 \\
-20.460 \\
* * *\end{array}$ & 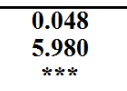 & $\begin{array}{l}-0.120 \\
-22.330 \\
\neq \neq=0\end{array}$ & $\begin{array}{l}-0.004 \\
-0.380\end{array}$ & $\begin{array}{l}0.000 \\
0.050\end{array}$ & $\begin{array}{l}-0.003 \\
-0.880\end{array}$ \\
\hline$\underset{\text { t-stat }}{\text { frm }}$ & $\begin{array}{c}-0.065 \\
-16.910 \\
* * * *\end{array}$ & $\begin{array}{c}0.023 \\
7.250 \\
\div * *\end{array}$ & $\begin{array}{c}-0.042 \\
-23.780 \\
* * * *\end{array}$ & $\begin{array}{c}0.064 \\
17.630 \\
* * *\end{array}$ & $\begin{array}{l}-0.015 \\
-\mathbf{5 . 2 0 0} \\
* * * *\end{array}$ & $\begin{array}{c}0.049 \\
29.940 \\
* * * *\end{array}$ & $\begin{array}{l}0.001 \\
0.190\end{array}$ & $\begin{array}{l}-0.007 \\
-2.500 \\
* *\end{array}$ & $\begin{array}{l}-0.006 \\
-\mathbf{5 . 0 5 0} \\
* * *\end{array}$ \\
\hline $\begin{array}{r}\mathbf{T P} \\
\text { t-stat }\end{array}$ & $\begin{array}{c}-0.209 \\
-25.250 \\
* * *\end{array}$ & $\begin{array}{l}0.042 \\
4.840 \\
* * * *\end{array}$ & $\begin{array}{c}-0.167 \\
-35.470 \\
* * *\end{array}$ & $\begin{array}{c}0.205 \\
23.150 \\
* * * *\end{array}$ & $\begin{array}{l}-0.045 \\
-\mathbf{5 . 5 3 0} \\
* * * *\end{array}$ & $\begin{array}{c}0.160 \\
38.510 \\
* * * *\end{array}$ & $\begin{array}{l}0.004 \\
0.450\end{array}$ & $\begin{array}{l}0.003 \\
0.380\end{array}$ & $\begin{array}{c}0.006 \\
1.970 \\
* *\end{array}$ \\
\hline $\begin{array}{r}\text { Term_Str } \\
\text { t-stat }\end{array}$ & $\begin{array}{c}-0.254 \\
-20.420 \\
* * * *\end{array}$ & $\begin{array}{c}0.088 \\
6.110 \\
* * * *\end{array}$ & $\begin{array}{c}-0.166 \\
-19.400 \\
* * *\end{array}$ & $\begin{array}{c}0.286 \\
19.500 \\
* * *\end{array}$ & $\begin{array}{c}-0.083 \\
-\mathbf{5 . 8 7 0} \\
* * * *\end{array}$ & $\begin{array}{c}0.202 \\
27.370 \\
* * * *\end{array}$ & $\begin{array}{c}-0.032 \\
-2.200 \\
* *\end{array}$ & $\begin{array}{l}-0.005 \\
-0.360\end{array}$ & $\begin{array}{l}-0.036 \\
-7.130 \\
* * *\end{array}$ \\
\hline$\underset{\text { t-stat }}{\text { R_Vol }}$ & $\begin{array}{c}0.006 \\
1.840 \\
*\end{array}$ & $\begin{array}{l}0.009 \\
2.850 \\
* * * *\end{array}$ & $\begin{array}{c}0.015 \\
4.830 \\
* * *\end{array}$ & $\begin{array}{l}-0.027 \\
-8.550 \\
* * *\end{array}$ & $\begin{array}{c}0.006 \\
2.040 \\
* *\end{array}$ & $\begin{array}{c}-0.021 \\
-12.140 \\
* * * *\end{array}$ & $\begin{array}{c}0.021 \\
6.950 \\
* * *\end{array}$ & $\begin{array}{l}-0.015 \\
-5.400 \\
* * *\end{array}$ & $\begin{array}{c}0.006 \\
2.860 \\
* * *\end{array}$ \\
\hline
\end{tabular}

Sources: Loan related data are from McDash Analytics. House price indexes are the CoreLogic house price indexes for single family homes by zip code.

Marginal effects are computed from the multinomial probit model with three non-ordered outcomes for mortgage financing (see Table 2). Marginal effects are evaluated at sample means of the mortgage pricing components. In the first column of each panel, the marginal effects are measured at zero house price appreciation and are scaled by the standard deviations of the independent variables for which the marginal effects are computed. In the second column of each panel, the marginal effects are from the interactions of house price appreciation and the mortgage pricing components. The marginal effects are calculated at the sample mean of house price appreciation and scaled by the standard deviations of the variables for which the marginal effects are calculated and the mean of house price appreciation. In the third column of each panel, the net effects are the sums of the effects in the first and second columns. The mortgage pricing components are defined in Table 1. 


\begin{tabular}{|c|c|c|c|c|c|}
\hline \multicolumn{6}{|c|}{$\begin{array}{l}\text { Lower House Price Appreciation Sample } \\
\text { Sample Period (2000q1 to 2007q3) }\end{array}$} \\
\hline \multicolumn{3}{|c|}{ A-ARMs (requiring principal and interest payments) } & \multicolumn{3}{|c|}{ AMPs (IO and Option ARMs) } \\
\hline \multicolumn{3}{|c|}{ Mortgage Pricing Components } & \multicolumn{3}{|c|}{ Mortgage Pricing Components } \\
\hline & HPI App $=0$ & \begin{tabular}{|c|} 
Interacted with HPI \\
App
\end{tabular} & & HPI App $=0$ & $\begin{array}{c}\text { Interacted with HPI } \\
\text { App }\end{array}$ \\
\hline $\begin{array}{r}\text { arm } \\
\text { t-stat }\end{array}$ & $\begin{array}{c}-0.976 \\
-20.920 \\
* * *\end{array}$ & $\begin{array}{c}0.006 \\
1.880 \\
*\end{array}$ & $\begin{array}{r}\text { arm } \\
\text { t-stat }\end{array}$ & $\begin{array}{c}-0.275 \\
-4.230 \\
* * *\end{array}$ & $\begin{array}{l}0.001 \\
0.280\end{array}$ \\
\hline $\begin{array}{r}\text { frm } \\
\text { t-stat }\end{array}$ & $\begin{array}{c}1.851 \\
17.770 \\
* * *\end{array}$ & $\begin{array}{l}-0.026 \\
-3.560 \\
* * *\end{array}$ & $\begin{aligned} \text { frm } \\
\text { t-stat }\end{aligned}$ & $\begin{array}{c}0.541 \\
3.500 \\
* * *\end{array}$ & $\begin{array}{c}-0.026 \\
-2.650 \\
* * *\end{array}$ \\
\hline $\begin{array}{r}\text { TP } \\
\text { t-stat }\end{array}$ & $\begin{array}{c}1.056 \\
27.260 \\
* * *\end{array}$ & $\begin{array}{l}-0.006 \\
-2.250 \\
* *\end{array}$ & $\begin{array}{r}\text { TP } \\
\text { t-stat }\end{array}$ & $\begin{array}{l}0.335 \\
6.260 \\
* * *\end{array}$ & $\begin{array}{l}-0.004 \\
-1.160\end{array}$ \\
\hline $\begin{array}{r}\text { Term_Str } \\
\text { t-stat }\end{array}$ & $\begin{array}{c}0.813 \\
22.220 \\
* * *\end{array}$ & $\begin{array}{l}-0.007 \\
-2.860 \\
* * *\end{array}$ & $\underset{\text { t-stat }}{\text { Term_Str }}$ & $\begin{array}{c}0.105 \\
1.920 \\
* *\end{array}$ & $\begin{array}{c}-0.006 \\
-1.730 \\
*\end{array}$ \\
\hline $\begin{array}{r}\text { R_Vol } \\
\text { t-stat }\end{array}$ & $\begin{array}{c}-0.006 \\
-7.350 \\
* * *\end{array}$ & $\begin{array}{c}0.00009 \\
1.600\end{array}$ & $\begin{array}{l}\text { R_Vol } \\
\text { t-stat }\end{array}$ & $\begin{array}{c}0.004 \\
2.810 \\
* * *\end{array}$ & $\begin{array}{c}0.000 \\
-1.020\end{array}$ \\
\hline \multicolumn{3}{|c|}{ Housing Market Related } & \multicolumn{3}{|c|}{ Housing Market Related } \\
\hline $\begin{array}{r}\text { HPI_App } \\
\text { t-stat }\end{array}$ & $\begin{array}{c}0.035 \\
3.350 \\
* * *\end{array}$ & & $\begin{array}{r}\text { HPI_App } \\
\text { t-stat }\end{array}$ & $\begin{array}{c}0.054 \\
4.410 \\
* * *\end{array}$ & \\
\hline $\begin{array}{r}\text { HPI_Vol } \\
\text { t-stat }\end{array}$ & $\begin{array}{l}-0.036 \\
-1.370\end{array}$ & & $\begin{array}{r}\text { HPI_Vol } \\
\text { t-stat }\end{array}$ & $\begin{array}{l}0.003 \\
0.110\end{array}$ & \\
\hline \multicolumn{3}{|c|}{ Loan/Borrower Related } & \multicolumn{3}{|c|}{ Loan/Borrower Related } \\
\hline $\begin{array}{l}\text { LTV } \\
\text { t-stat }\end{array}$ & $\begin{array}{c}-0.001 \\
-2.050 \\
* *\end{array}$ & & $\begin{array}{l}\text { LTV } \\
\text { t-stat }\end{array}$ & -1.660 & \\
\hline $\begin{array}{l}\text { LTV80 } \\
\text { t-stat }\end{array}$ & \multicolumn{2}{|l|}{$\begin{array}{c}0.249 \\
16.810 \\
* * *\end{array}$} & $\begin{array}{l}\text { LTV80 } \\
\text { t-stat }\end{array}$ & \multicolumn{2}{|l|}{$\begin{array}{c}0.390 \\
33.700 \\
* * *\end{array}$} \\
\hline $\begin{array}{r}\text { Conform } \\
\text { t-stat }\end{array}$ & \multicolumn{2}{|l|}{$\begin{array}{c}-1.087 \\
-40.190 \\
* * *\end{array}$} & $\begin{array}{r}\text { Conform } \\
\text { t-stat }\end{array}$ & \multicolumn{2}{|l|}{$\begin{array}{c}-1.410 \\
-40.870 \\
* * *\end{array}$} \\
\hline $\begin{array}{r}\text { Credit_Risk } \\
\text { t-stat }\end{array}$ & \multicolumn{2}{|l|}{$\begin{array}{c}-0.005 \\
-33.950 \\
* * *\end{array}$} & $\begin{array}{r}\text { Credit_Risk } \\
\text { t-stat }\end{array}$ & $\begin{array}{c}-0.004 \\
-36.240 \\
* * *\end{array}$ & \\
\hline $\begin{array}{l}\text { Pr_Inc } \\
\text { t-stat }\end{array}$ & \multicolumn{2}{|l|}{$\begin{array}{c}0.022 \\
5.300 \\
* * *\end{array}$} & $\begin{array}{r}\text { Pr_Inc } \\
\text { t-stat }\end{array}$ & \multicolumn{2}{|l|}{$\begin{array}{c}0.084 \\
13.750 \\
* * *\end{array}$} \\
\hline$\underset{\text { t-stat }}{\text { Inc_Risk }}$ & \multicolumn{2}{|l|}{$\begin{array}{l}-0.017 \\
-1.370\end{array}$} & $\underset{\text { t-stat }}{\text { Inc_Risk }}$ & \multicolumn{2}{|l|}{$\begin{array}{l}-0.020 \\
-1.040\end{array}$} \\
\hline \multicolumn{3}{|c|}{$2,003,724$} & & & \\
\hline
\end{tabular}

Sources: Loan related data are from McDash Analytics. Borrower income are from the Home Mortgage Disclosure Act (HMDA) databases. House price indexes are the CoreLogic house price indexes for single family homes by zip code.

The sample includes observations for which house price appreciation is below the 75th percentile of the sample distribution. The model is a multinomial probit with three non-ordered outcomes for mortgage choice: fixed-rate mortgages, adjustable-rate mortgages requiring interest and principal payments (A-ARM); and alternative adjustable-rate mortgages with back-loading of repayment of principal (AMP), which include option and interest-only adjustable-rate mortgages. The observations for the types of mortgages are loan-level. The loans are first-liens for home purchases by primary occupants. The probit estimations control for year-fixed effects and state-fixed effects. Levels of significance are based on robust standard errors clustered on counties. The sample also was filtered to include only loans with original loan-to-value ratios greater than 10 percent and less than 110 percent. Observations with house-price-to-income ratios above the 99th percentile or below the first percentile were dropped. Observations were excluded if the borrower did not report positive income and for those reporting income in top income code. The mortgage pricing components are averages for the quarter in which a loan was closed. Variable definitions are provided in Table 1. 
Table 5. Marginal Effects on Probabilities of Mortgage Selection Outcomes: Lower House Price Appreciation Sample Mortgage Pricing Components

Sample Period (2000q1 to 2007q3) Number of Observations $(2,003,724)$ $*, *$, and $* *$ denote significance at the 10,5 and 1 percent levels, respectively

\begin{tabular}{|c|c|c|c|c|c|c|c|c|c|}
\hline & \multicolumn{3}{|c|}{ Fixed-Rate Mortgages } & \multicolumn{3}{|c|}{$\begin{array}{c}\text { A-ARMs } \\
\begin{array}{c}\text { (requiring principal and interest } \\
\text { payments) }\end{array} \\
\end{array}$} & \multicolumn{3}{|c|}{$\begin{array}{c}\text { AMPs } \\
\text { (IO and Option ARMs) } \\
\end{array}$} \\
\hline $\begin{array}{l}\text { Mortgage } \\
\text { Pricing } \\
\text { Components }\end{array}$ & \begin{tabular}{|l} 
HPI App \\
equal to zero
\end{tabular} & $\begin{array}{l}\text { HPI App at } \\
\text { sample mean }\end{array}$ & $\begin{array}{c}\text { Net } \\
\text { HPI App } \\
\text { at sample } \\
\text { mean }\end{array}$ & \begin{tabular}{|l} 
HPI App \\
equal to zero
\end{tabular} & $\begin{array}{l}\text { HPI App at } \\
\text { sample mean }\end{array}$ & $\begin{array}{c}\text { Net } \\
\text { HPI App } \\
\text { at sample } \\
\text { mean }\end{array}$ & \begin{tabular}{|c} 
HPI App \\
equal to zero
\end{tabular} & $\begin{array}{l}\text { HPI App at } \\
\text { sample mean }\end{array}$ & $\begin{array}{c}\text { Net } \\
\text { HPI App } \\
\text { at sample } \\
\text { mean } \\
\end{array}$ \\
\hline arm & 0.141 & -0.010 & 0.131 & -0.138 & 0.010 & -0.128 & -0.003 & 0.000 & -0.003 \\
\hline p-stat & $\begin{array}{c}18.760 \\
* * * *\end{array}$ & -1.490 & $\begin{array}{c}24.680 \\
* * *\end{array}$ & $\begin{array}{c}-19.270 \\
* * *\end{array}$ & $\begin{array}{c}1.880 \\
*\end{array}$ & $\begin{array}{c}-23.470 \\
* * * *\end{array}$ & -0.440 & -0.070 & -0.720 \\
\hline frm & -0.062 & 0.014 & -0.048 & 0.060 & -0.009 & 0.051 & 0.002 & -0.005 & -0.003 \\
\hline p-stat & $\underset{* * *}{-14.670}$ & $\begin{array}{c}3.890 \\
* * *\end{array}$ & $\underset{* * *}{-22.880}$ & $\begin{array}{c}16.860 \\
* * *\end{array}$ & $\begin{array}{c}-3.130 \\
* * *\end{array}$ & $\underset{* * *}{25.850}$ & 0.480 & $\begin{array}{c}-2.080 \\
* *\end{array}$ & $\begin{array}{c}-2.260 \\
* *\end{array}$ \\
\hline $\mathbf{T P}$ & -0.180 & 0.013 & -0.167 & 0.173 & -0.010 & 0.163 & 0.007 & -0.004 & 0.004 \\
\hline p-stat & $\begin{array}{c}-23.920 \\
* * *\end{array}$ & $\underset{* *}{2.180}$ & $\underset{* * *}{-35.510}$ & $\begin{array}{c}24.770 \\
* * *\end{array}$ & $\begin{array}{l}-2.060 \\
* *\end{array}$ & $\begin{array}{c}34.680 \\
* * *\end{array}$ & 1.280 & $-\mathbf{- 0 . 8 0 0}$ & 1.200 \\
\hline Term_Str & -0.210 & 0.030 & -0.181 & 0.229 & -0.021 & 0.208 & -0.018 & -0.009 & -0.027 \\
\hline p-stat & $\begin{array}{c}-18.540 \\
* * *\end{array}$ & $\underset{* * *}{3.140}$ & $\underset{* * *}{-22.250}$ & $\begin{array}{c}20.350 \\
* * *\end{array}$ & $\begin{array}{c}-2.500 \\
* *\end{array}$ & $\begin{array}{c}26.550 \\
* * *\end{array}$ & $\begin{array}{l}-1.770 \\
*\end{array}$ & -1.200 & $\begin{array}{l}-4.780 \\
* * *\end{array}$ \\
\hline R_Vol & 0.012 & -0.002 & 0.011 & -0.025 & 0.005 & -0.020 & 0.013 & -0.003 & 0.010 \\
\hline p-stat & $\begin{array}{c}3.070 \\
* * * *\end{array}$ & -0.490 & $\begin{array}{c}3.740 \\
* * *\end{array}$ & $\begin{array}{c}-8.330 \\
* * * *\end{array}$ & $\begin{array}{c}1.960 \\
* *\end{array}$ & $\underset{* * *}{-10.280}$ & $\begin{array}{c}4.080 \\
* * *\end{array}$ & -1.360 & $\begin{array}{c}5.740 \\
* * * *\end{array}$ \\
\hline
\end{tabular}

Sources: Loan related data are from McDash Analytics. House price indexes are the CoreLogic house price indexes for single family homes by zip code.

The sample includes observations for which house price appreciation is below the 75th percentile of of the sample distribution. Marginal effects are computed from a multinomial probit model with three non-ordered outcomes for mortgage financing (See Table 5). The marginal effects are measured at the means of the mortgage pricing components for observations for which the house price appreciation is below the 75th percentile of the sample distribution. In the first column of each panel, the marginal effects are measured at zero house price appreciation and are scaled by the standard deviations of the independent variables for which the marginal effects are computed. The second column of each panel reports the marginal effects from the interactions of with house price appreciation and the mortgage pricing components. Using only the observations for which house price appreciation is below the 75th percentile, the marginal effects are calculated at the mean of house price appreciation and scaled by the standard deviations of the variables for which the marginal effects are computed and by the mean of house price appreciation. In the third column of each panel, the net effects are the sums of the effects in the first and second columns. The mortgage pricing and interest-rate-related variables are defined in Table 1. 
Table 6. Marginal Effects on Probabilities of Mortgage Selection Outcomes

House Price Appreciation

Sample Period (2000q1 to 2007q3)

$*, * *$, and $* * *$ denote significance at the 10,5 and 1 percent levels, respectively

\begin{tabular}{|r|cc|cc|}
\hline & \multicolumn{2}{|c|}{ Full sample } & \multicolumn{2}{c|}{$\begin{array}{c}\text { Lower House Price Appreciation } \\
\text { Sample }\end{array}$} \\
\hline & $\begin{array}{c}\text { Mortgage } \\
\text { Pricing } \\
\text { Components }\end{array}$ & $\begin{array}{c}\text { Net } \\
\text { Mortgage type }\end{array}$ & $\begin{array}{c}\text { Mortgage } \\
\text { Pricing } \\
\text { Components } \\
\text { equal to zero }\end{array}$ & at sample means \\
equal to zero & at sample means \\
\hline Fixed Rate & -0.157 & -0.006 & -0.071 & 0.001 \\
t-stat & -7.520 & -1.890 & -4.540 & 0.390 \\
& $* * *$ & $*$ & $* * *$ & \\
A-ARM & 0.067 & 0.006 & 0.034 & 0.002 \\
t_stat & 4.140 & 3.030 & 2.640 & 1.450 \\
& $* * *$ & $* * *$ & $* * *$ & \\
AMP & 0.090 & 0.000 & 0.038 & -0.003 \\
t-stat & 7.050 & -0.100 & 3.890 & -1.660 \\
& $* * *$ & & $* * *$ & $*$ \\
\hline
\end{tabular}

Sources: Loan related data are from McDash Analytics. House price indexes are CoreLogic house price indexes for single family homes by zip codes.

Marginal effects are computed from the multinomial probit models with three nonordered outcomes for mortgage financing (see Tables 2 and 4). The table shows results for each of the three alternatives. In the first panel, the marginal effects are derived from the probit estimation results presented in Table 2 and are evaluated at the mean of house price appreciation (HPI_App) for the full sample. In the second panel, the marginal effects are derived from the probit estimation results presented in Table 4 and are evaluated at the mean of house price appreciation (HPI_App) for the observations below the 75th percentile of the sample distribution. In the first column of each panel, the mortgage pricing components are set to zero and the estimated effects are scaled by the standard deviation of house price appreciation for respective sample. The second column of each panel reports the net marginal effects of house price appreciation after taking into account the effects from the interaction of house price appreciation and the mortgage pricing components. The mortgage pricing components are described in Table 1. 